University of Nebraska - Lincoln

DigitalCommons@University of Nebraska - Lincoln

Agronomy \& Horticulture - Faculty Publications

Agronomy and Horticulture Department

February 2007

\title{
Understanding and modeling the effect of temperature and daylength on soybean phenology under high-yield conditions
}

\author{
T. D. Setiyono \\ University of Nebraska-Lincoln, tsetiyono2@unl.edu \\ Albert Weiss \\ University of Nebraska-Lincoln, aweiss1@unl.edu \\ James E. Specht \\ University of Nebraska-Lincoln, jspecht1@unl.edu
}

\author{
A. M. Bastidas \\ University of Nebraska-Lincoln \\ Kenneth G. Cassman \\ University of Nebraska-Lincoln, kcassman1@unl.edu
}

See next page for additional authors

Follow this and additional works at: https://digitalcommons.unl.edu/agronomyfacpub

Part of the Plant Sciences Commons

Setiyono, T. D.; Weiss, Albert; Specht, James E.; Bastidas, A. M.; Cassman, Kenneth G.; and Dobermann, A., "Understanding and modeling the effect of temperature and daylength on soybean phenology under highyield conditions" (2007). Agronomy \& Horticulture -- Faculty Publications. 112.

https://digitalcommons.unl.edu/agronomyfacpub/112

This Article is brought to you for free and open access by the Agronomy and Horticulture Department at DigitalCommons@University of Nebraska - Lincoln. It has been accepted for inclusion in Agronomy \& Horticulture -Faculty Publications by an authorized administrator of DigitalCommons@University of Nebraska - Lincoln. 


\section{Authors}

T. D. Setiyono, Albert Weiss, James E. Specht, A. M. Bastidas, Kenneth G. Cassman, and A. Dobermann 
Published in Field Crops Research 100:2-3 (February 1, 2007), pp. 257-271; doi 10.1016/j.fcr.2006.07.011

Copyright (C) 2006 Elsevier B.V. Used by permission. http://www.sciencedirect.com/science/journal/03784290

Submitted April 24, 2006; revised July 28, 2006; accepted July 28, 2006; published online September 8, 2006.

\title{
Understanding and modeling the effect of temperature and daylength on soybean phenology under high-yield conditions
}

\author{
T. D. Setiyono ${ }^{1}$, A. Weiss ${ }^{2}$, J. Specht ${ }^{1}$, A. M. Bastidas ${ }^{1}$, K. G. Cassman ${ }^{1}$, and A. Dobermann ${ }^{1}$ \\ ${ }^{1}$ Department of Agronomy and Horticulture, University of Nebraska-Lincoln, P.O. Box 830915, Lincoln, NE 68583-0915, USA \\ ${ }^{2}$ School of Natural Resources, University of Nebraska-Lincoln, P.O. Box 830728, Lincoln, NE 68583-0728, USA \\ Corresponding author: A. Dobermann, tel 402 472-1501, fax 402 472-7904, email adobermann2@unl.edu
}

\begin{abstract}
Temperature and photoperiod can be used to simulate soybean (Glycine max [L.] Merr) phenology because they serve as surrogates for complex biochemical pathways leading to the appearance of certain developmental stages at the whole plant level. We developed a soybean phenology model (SOYDEV) which utilizes non-linear temperature and photoperiod functions and separates floral induction and post-induction for simulating time of flowering. This model accurately simulated the dynamics of vegetative development, final node number and the occurrence of major reproductive stages such as flowering $\left(R_{1}\right)$, beginning pod $\left(R_{3}\right)$, mid-pod elongation $\left(R_{3.5}\right)$, beginning seed $\left(R_{5}\right)$, and physiological maturity $\left(R_{7}\right)$ in a longterm field experiment (6 years) with the semi-determinate soybean cv. NE3001, as well as in a 2-year cultivar $\times$ sowing date experiment with 12 (2004) and 8 (2005) cultivars. With cultivar-specific model calibration, root mean square errors (RMSE) of major phenological stages simulated with SOYDEV averaged 1.8 days in the long-term experiment and 3.3 days in the cultivar $\times$ sowing date experiment. Data from the cultivar $\times$ sowing date experiment were used to develop empirical relationships for estimating key cultivar-specific model parameters from published soybean maturity group ratings (0.8-4.2). Compared to using nine cultivar-specific parameters derived from the full calibration, estimation of model parameters from readily available cultivar information such as maturity group rating only slightly decreased simulation accuracy, resulting in RMSE (across stages and cultivars) values of 3.6-3.8 days. The proposed SOYDEV model may be particularly suitable for practical model applications because of its reduced need for cultivar-specific calibration. Further evaluation of the model is required under a wider range of variety maturity group ratings and environments.
\end{abstract}

Keywords: soybean, Glycine max, phenology, temperature, photoperiod, flowering, maturity, beta function, simulation, modeling

\section{Introduction}

Simulating crop phenology at the whole plant level is considered more effective than alternative approaches that focus on plant organ or cellular levels (Trewavas, 1986, Wallace et al., 1993 and Zobel, 1992). The most commonly used whole plant phenology staging system for soybean (Glycine max [L.] Merr) was developed by Fehr and Caviness (1977). In this system, vegetative development begins at emergence when cotyledons appear above the soil surface. Stages following emergence include cotyledon, unifoliate, and trifoliolate nodes. The newest node is assigned a number on the basis of the status of the leaf at a node above it; if unrolled (leaf edges are not touching), then the node below is assigned a number. The beginning flower stage $\left(\mathrm{R}_{1}\right)$ indicates the initiation of the reproductive phase and is marked by the first open flower on the main stem. The beginning pod $\left(\mathrm{R}_{3}\right)$ occurs when a pod of at least $5 \mathrm{~mm}$ length is found at one of the four uppermost nodes on the main stem. The mid-pod elongation stage $\left(\mathrm{R}_{3.5}\right)$ occurs when a pod 10-12 mm long is found at one of the four uppermost nodes on the main stem the mid-pod elongation stage and can be used as a key indicator for irrigation. $\mathrm{R}_{3.5}$ is also when vegetative stem and leaf development ceases in most indeterminate cultivars. The beginning seed stage $\left(R_{5}\right)$ indicates the beginning of the linear seed filling and is marked by the presence of seeds of at least $3 \mathrm{~mm}$ in any of the four uppermost nodes. Physiological maturity $\left(\mathrm{R}_{7}\right)$ indicates the end of the reproductive phase and is marked by the presence of one mature pod of brown or tan color at any node on the main stem.

In cereals, the transition from vegetative to reproductive development is distinct, whereas in soybean, and other crops exhibiting indeterminate habit, reproductive and vegetative development co-exist for some proportion of the crop life cy- 
cle. New inflorescences appear at the auxiliary meristem of soybean while new nodes bearing trifoliolates are being initiated at the apical meristem. In determinate and semi-determinate soybean genotypes, the apical meristem eventually becomes a raceme, thus ending the vegetative activity at the stem apex. In indeterminate types, this transition is less abrupt and is influenced by competition for assimilates by the growing seeds at existing nodes. Therefore, a functional definition of the vegetative phase in soybean is duration from emergence to the end of node appearance, and we rely on this definition hereafter.

The two dominant abiotic factors influencing soybean phenology are temperature and photoperiod (Cregan and Hartwig, 1984, Hesketh et al., 1973, and Summerfield and Wilcox, 1978). Temperature generally has a positive influence on the rate of crop development. Photoperiod, modifies the temperature response in soybean, a short-day plant, in that long daylength slows the development rate. The maturity group classification for soybean cultivars in the U.S. is based on soybean development response to photoperiod (Heatherly and Elmore, 2004). Simulating phenology under optimum growth and development conditions requires quantification of temperature and photoperiod responses. However, since water and nutrient stress also influence development rate in soybean (Brevedan and Egli, 2003, Brown and Chapman, 1960, Robins and Domingo, 1956, Sinclair and deWit, 1975, and Sinclair and deWit, 1976), evaluating temperature and photoperiod effects per se on phenology requires non-limiting water and nutrient conditions under field conditions.

When only temperature and photoperiod are considered for simulating phenology, options for an overall algorithm include multiplicative (Grimm et al., 1993, Hodges and French, 1985, Jones et al., 2000, Major et al., 1975, Streck et al., 2003, and Wang and Engel, 1998), additive (Sinclair et al., 1991, Steward et al., 2003, and Summerfield et al., 1991), subtractive (Steward et al., 2003), or a mixture of additive and multiplicative approaches (Cober et al., 2001). The multiplicative approach is widely used in crop models such as WOFOST, STICS, or CROPGRO (Boogard et al., 1998, Brisson et al., 1998, and Jones et al., 2000). In these algorithms, the development rate is assumed to increase linearly with temperature above a certain critical base temperature, with or without a plateau representing maximum growth rate at an optimal temperature. Models with a plateau above the optimal temperature are analogues to an accumulated thermal time $\left({ }^{\circ} \mathrm{C} d\right)$ approach (Wilhelm and McMaster, 1995). The development rate may also decrease at high temperature (Hesketh et al., 1973) and thus a spline function is sometimes used to model this decrease in development rate. CROPGRO uses a linear spline function to reflect the response of development rate to a high temperature (Jones et al., 2000). In rice, the use of a non-linear temperature function was found to offer better accuracy in phenology simulation than an accumulated thermal time approach (Yin et al., 1995).

Photoperiod is typically treated as a modifier to the effect of temperature, and in the case of soybean, a quantitative short-day plant, longer daylength decreases the development rate by delaying reproductive development. Experiments involving manipulation of light by red and far red wavelengths led to the acceptance of the phytochrome-mediated regulation of flowering in response to photoperiod in short- and long-day plants (Leopold and Kriedemann, 1975 and Naylor, 1953). Leaves are the receptor of photoperiod signals leading to regulation of flowering in soybean and other plants (Thomas and Vince-Prue, 1997). Considering the well-known photoperiod flower induction response in soybean, the use of a photoperiod function in soybean phenology modeling is reasonable. Most soybean phenology research on photoperiod response has focused on developing a photoperiod function for flowering (Grimm et al., 1993, Grimm et al., 1994, Major et al., 1975, and Steward et al., 2003). However, the empirical evidence of responsiveness of soybean post-flowering development to daylength (Johnson et al., 1960, Shibles, 1978, and Summerfield et al., 1998), the proposed involvement phytochromes as receptors for photoperiod signal during post-flowering phase (Han et al., 2006), and the existent of genes controlling time of maturity (independent of flowering time) in soybean (McBlain et al., 1987) suggest that photoperiod response function should also be considered in modeling postflowering soybean development.

The objectives of this study were to gain a better understanding of the governing processes of soybean phenology associated with its responses to temperature and/or photoperiod and to develop a robust soybean phenology model for a highyield environment. The successful application of crop simulation models in practice often hinges on the availability of cultivar-specific input parameters, which are usually obtained from carefully conducted field experiments. If these data are not available, a simulation model can be run with generic, default parameters, but the practical use of such a model may then be limited by the potential decrease in simulation accuracy. We hypothesized that key model parameters required for simulating soybean phenology can be estimated from readily available cultivar-specific information such as maturity group (MG) rating and stem termination habit, and that this simplification would lead to only a small loss of simulation accuracy.

\section{Materials and methods}

\subsection{Field experiments}

Data for the SOYDEV model development and evaluation were obtained from a long-term high-yield experiment (1999$2005)$ and a cultivar $\times$ sowing date experiment (2004-2005) conducted at the University of Nebraska-Lincoln $\left(40^{\circ} 49^{\prime \prime} \mathrm{N}\right.$, $96^{\circ} 39^{\prime \prime} \mathrm{W}, 357 \mathrm{~m}$ above sea level), where soybean was grown with full irrigation in rotation with maize. The soil type was Kennebec silt loam (fine-silty, mixed, superactive, mesic $\mathrm{Cu}$ mulic Hapludolls), initially containing $2.7 \%$ organic matter, $67 \mathrm{mg} \mathrm{kg}^{-1}$ Bray P1, and $350 \mathrm{mg} \mathrm{kg}^{-1}$ extractable $\mathrm{K}$ in 0 $0.2 \mathrm{~m}$ depth. Weeds were controlled by pre-plant application of $0.23 \mathrm{~kg} \mathrm{ha}^{-1}$ flufenacet [ $N$-(4-fluorophenyl)- $N$-(1-methylethyl)-2-[[5-(trifluoromethyl)-1,3,4-thiadiazol-2-yl]oxy] acet- 
amide] and $0.06 \mathrm{~kg} \mathrm{ha}^{-1}$ metribuzin [4-amino-6-tert-butyl4,5-dihydro-3-methylthio-1,2,4-triazin-5-one] and in-season manual hoeing. Pests and diseases were managed to avoid yield loss, with particular emphasis on avoiding outbreaks of white mold (Sclerotinia sclerotiorum), soybean aphids (Aphis glycines), and been leaf beetles (Ceratoma trifurcate) with the associated bean pod mottle virus (genus Comovirus, family Comoviridae).

The long-term, high-yield experiment (1999-2005) was designed to evaluate year to year differences in soybean development and yield potential. The cultivar used in this study was NE3001, a semi-determinate cultivar with a relative maturity group rating of 3.0. Row spacing in the treatments used here was $0.76 \mathrm{~m}$ (1999-2002, and 2005) and $0.385 \mathrm{~m}$ (2004). Sowing density ranged from 247,000 to 494,000 viable seeds ha ${ }^{-1}$. Sowing depth was approximately $2.5 \mathrm{~cm}$ and sowing dates varied from 26 April to 15 May among the different years. Tillage consisted of fall plowing followed by field cultivation in spring for seedbed preparation. Irrigation was applied with a surface drip tape system (1999 and 2000), a sub-surface drip tape system (2001 and 2002), or a solidset sprinkler system (2004-2005). Irrigation generally commenced at the $\mathrm{R}_{3}-\mathrm{R}_{3.5}$ stage and was scheduled to replenish the estimated daily evapotranspiration obtained from an automated weather station located within $500 \mathrm{~m}$ of the experimental site. Such an irrigation regime is optimal for soybean in the Western Corn Belt (Kadhem et al., 1985a, Kadhem et al., 1985b, Korte et al., 1983a, Korte et al., 1983b, and Specht et al., 1989). An automated weather station (maintained by the High Plains Regional Climate Center, http://www.hprcc.unl. edu) estimated daily evapotranspiration based on reference evapotranspiration (Penman method) and a crop coefficient derived from accumulated thermal time $\left({ }^{\circ} \mathrm{C} \mathrm{d}\right)$ from sowing to maturity. Nutrient applications included $80 \mathrm{~kg} \mathrm{~N} \mathrm{ha}^{-1}$ (at $\mathrm{R}_{3.5}$ stage), $45 \mathrm{~kg} \mathrm{P} \mathrm{ha}^{-1}$ and $85 \mathrm{~kg} \mathrm{~K} \mathrm{ha}^{-1}$ (pre-plant). The experimental plots were $15.2 \mathrm{~m} \times 6.1 \mathrm{~m}$ (eight rows in 1999-2002 and 2005, and 15 rows in 2004) with four replicates. The harvested area was $9.14 \mathrm{~m} \times 1.52 \mathrm{~m}$ (two non-border rows) for the $0.76 \mathrm{~m}$ row spacing and $9.14 \mathrm{~m} \times 1.15 \mathrm{~m}$ (three non-border rows) for the $0.385 \mathrm{~m}$ row spacing. Plants were manually harvested and machine threshed. Soybean yields (adjusted to $13 \%$ moisture) obtained in the high-yield experiment ranged from 4.3 to $5.9 \mathrm{Mg} \mathrm{ha}^{-1}$.

In the cultivar $\times$ sowing date experiment, several soybean cultivars (Table 1) ranging in MG rating from 3.0 to 3.9 in 2004 and from 0.8 to 4.2 in 2005 were grown at $0.76 \mathrm{~m}$ row spacing and a sowing density of 370,000 viable seeds ha ${ }^{-1}$. The sowing date treatments were 28 April, 16 May, 2 June, and 17 June in 2004; 15 April, 5 May, and 24 May in 2005. Tillage included plowing in fall and field cultivation in spring for seedbed preparation. Irrigation was applied with a solidset sprinkler system and scheduled to replenish the estimated daily evapotranspiration (obtained from an automated weather station located within $500 \mathrm{~m}$ distance of the experimental site) for cv. NE3001 in the first sowing date treatment. No nutrients were applied to soybean in the cultivar $\times$ sowing date experiment because soil testing indicated that available $\mathrm{P}$ and $\mathrm{K}$ were
Table 1. Cultivars used in the cultivar $\times$ sowing date experiment in 2004 and 2005 at Lincoln, NE

\begin{tabular}{clcc}
\hline Year & Cultivar & Maturity group & Stem termination type \\
\hline 2004 & NE3001 & 3.0 & Semi-determinate \\
& Dekalb 3152 & 3.1 & Indeterminate \\
& Latham 1067RR & 3.1 & Indeterminate \\
NEX8903 & 3.1 & Indeterminate \\
Krueger 323RR & 3.2 & Indeterminate \\
NE3201 & 3.2 & Indeterminate \\
KAUP 335 & 3.3 & Indeterminate \\
Pioneer 93B63 & 3.3 & Indeterminate \\
Asgrow 3401 & 3.4 & Indeterminate \\
Pioneer 93B47 & 3.4 & Indeterminate \\
Stine 3632 & 3.4 & Indeterminate \\
U98 307917 & 3.4 & Indeterminate \\
U98 307162 & 3.6 & Indeterminate \\
U98 311442 & 3.9 & Indeterminate \\
& & & \\
Asgrow 0801 & 0.8 & Indeterminate \\
Dekalb 1552 & 1.5 & Indeterminate \\
U01-290401 & 1.6 & Semi-determinate \\
U01-390224 & 2.5 & Semi-determinate \\
Dekalb 2653 & 2.6 & Indeterminate \\
NE3001 & 3.0 & Semi-determinate \\
Pioneer 93B63 & 3.1 & Indeterminate \\
Dekalb 4251 & 4.2 & Indeterminate \\
& & \\
\hline
\end{tabular}

far above recommended critical levels of $12 \mathrm{mg} \mathrm{P} \mathrm{kg}^{-1}$ or $124 \mathrm{mg} \mathrm{K} \mathrm{kg}^{-1}$ (Ferguson et al., 2003). The experimental plots were $4.57 \mathrm{~m} \times 3.05 \mathrm{~m}$ (four rows) and consists of four replications. The harvested area was $4.27 \mathrm{~m} \times 1.52 \mathrm{~m}$ (two middle rows) and a small plot combine was used for harvesting. Soybean yields (adjusted to $13 \%$ seed moisture) ranged from 2.4 to $5.5 \mathrm{Mg} \mathrm{ha}^{-1}$ in 2004 and 3.0 to $5.9 \mathrm{Mg} \mathrm{ha}^{-1}$ in 2005. In both years, yield generally declined with later sowing (Bastidas, 2005).

\subsection{Phenology and climate measurements}

In both experiments, emergence date was determined when at least $50 \%$ of the cotyledons of the seedlings were above the soil surface. The subsequent phenology data were collected by non-destructive random sampling of 10 plants, to determine main stem node appearance from unifoliate $\left(\mathrm{V}_{1}\right)$ to the final main stem node $\left(\mathrm{V}_{n}\right)$, first open flower $\left(\mathrm{R}_{1}\right)$, first pod $\left(\mathrm{R}_{3}\right)$, mid-pod elongation $\left(R_{3.5}\right)$, beginning seed $\left(R_{5}\right)$, and physiological maturity $\left(\mathrm{R}_{7}\right)$ (Fehr and Caviness, 1977). Phenological sampling was conducted at 3-4 days intervals.

Daily weather data were obtained from the automatic weather station located within $500 \mathrm{~m}$ distance of the field experiment. Mean daily temperature (average of maximum and minimum) was used as the temperature input in the SOYDEV. Daylength was calculated using the algorithm described in Keisling (1982). Data from the literature and field experiments were used to estimate model parameters (Table 1). Maximum development rates and cardinal temperatures, in several cases, were estimated using SAS NLIN procedure (SAS Institute, 1999). Phenological sampling was conducted in more detail in 2004 than 


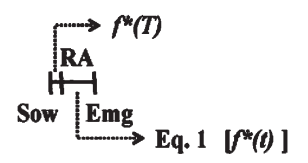

(a) Emergence

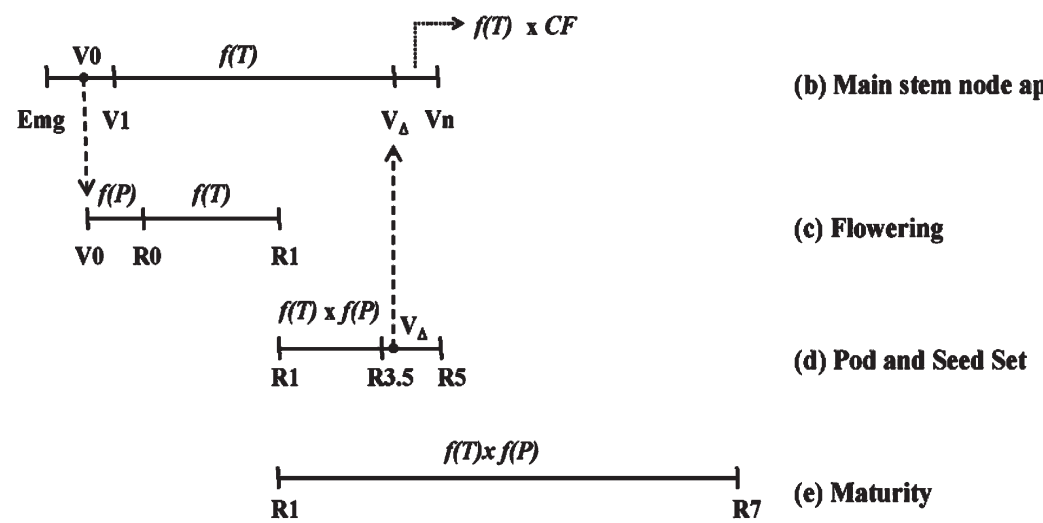

Figure 1. Phenological sequence simulated in SOYDEV. Phases were organized into main-phases (a-e), sub-phases (sub-division within each main phase), and mid-phases (segment within a main or sub-phase for simulating a stage of interest within that main or sub-phase). Type of function(s) used in simulating each of the main phases and sub-phases were schematically shown. Sow, sowing; RA, radicle appearance; Emg, emergence; $V_{0}$, cotyledon stage; $V_{1}$, unifoliate stage; $R_{0}$, end of floral induction; $\mathrm{R}_{1}$, first flower; $\mathrm{R}_{3.5}$, mid-pod elongation; $\mathrm{V}_{n}$, end of main stem node appearance; $f^{*}(T)$, accumulated thermal time; Equation (1) [ $f^{*}(T)$ ], Equation (1) as a function of accumulated thermal time; $f(T)$, temperature function; $f(P)$, photoperiod function; dashed arrow, information flow across two main phases; $\mathrm{V}_{\Delta}$, beginning of reduction in main stem node appearance rate; $\mathrm{CF}$, chronological function describing reduction in main stem node appearance rate.

in other years and therefore these data were used for model calibration, particularly for estimating some of the cardinal temperature and the maximum development rates as noted previously. For the cultivar $\times$ sowing date experiment, sowing dates representing the highest yields in each year (28 April in 2004 and 5 May in 2005) were used for cultivar-specific calibrations.

\subsection{Model development}

SOYDEV simulates soybean phenology based on five main phases, Figure 1. The first phase, from sowing to emergence, is based on accumulated thermal time during radicle development (sowing - radicle appearance, RA) and hypocotyl elongation (RA-emergence, Figure 1a). The next main phase is from emergence to final main stem node $\left(\mathrm{V}_{n}\right)$ and is a function of temperature and a chronology function describing reduction of main stem node appearance rate (Figure 1b). Since soybean development is not sequential, as in cereals, the beginning of reproductive phase overlaps with continuing vegetative phase. Therefore, the next main phase, which ends at the first open flower $\left(\mathrm{R}_{1}\right)$, commences at the cotyledon stage $\left(\mathrm{V}_{0}\right.$, Figure $1 c)$, and is a function of photoperiod during the floral induction phase $\left(\mathrm{V}_{0}-\mathrm{R}_{0}\right)$ and temperature during the post-induction phase $\left(R_{0}-R_{1}\right)$. The subsequent main phase, which ends at beginning seed $\left(R_{5}\right)$ was a function of temperature and photoperiod (Figure 1d). Just prior to $\mathrm{R}_{5}$, the chronology function (Figure 2) was employed to decrease main stem node appearance in the vegetative phase (Figure 1b). The onset of reduction in main stem node appearance rate $\left(\mathrm{V}_{\Delta}\right)$ was simulated based on mid-phase $R_{1}-V_{\Delta}$. The maturity main phase $\left(R_{1}-R_{7}\right)$ was also a function of temperature and photoperiod (Figure 1e).

Emergence was simulated in SOYDEV using a similar approach as in STICS (Brisson et al., 2003), where the radicle appearance (RA) and hypocotyl elongation were simulated sequentially. Radicle appearance was simulated when the accu- mulated thermal time (base temperature of $5^{\circ} \mathrm{C}$ ) was at $40^{\circ} \mathrm{C}$ days. Afterwards, hypocotyl length $\left(H_{\mathrm{L}}\right)$ was calculated using the accumulated thermal time from radicle appearance until emergence:

$$
H_{\mathrm{L}}=H_{\max }\left[1-\mathrm{e}^{\left(-a \mathrm{ATT}_{\mathrm{ra}}^{b}\right)}\right]
$$

where $a$ and $b$ are constants, $H_{\max }$ is the maximum hypocotyl length $(\mathrm{cm}), T_{\mathrm{b}}$ the base temperature $\left({ }^{\circ} \mathrm{C}\right)$, and $\mathrm{ATT}_{\mathrm{ra}}$ is the accumulated thermal time since radicle appearance $\left({ }^{\circ} \mathrm{C} \mathrm{d}\right)$. The values of $a, b, H_{\max }$, and $T_{\mathrm{b}}$ used in SOYDEV were 0.0128 , $4.57,5 \mathrm{~cm}$, and $5^{\circ} \mathrm{C}$, respectively. The value $a$, was derived from observed data in 2004, while $b, H_{\text {max }}$, and $T_{\mathrm{b}}$ were parameters given for soybean in STICS (Brisson et al., 2003). Emergence is defined as when the hypocotyl length exceeds sowing depth plus $0.6 \mathrm{~cm}$. This latter value was added to ensure that emergence represents the cotyledon being above the soil surface.

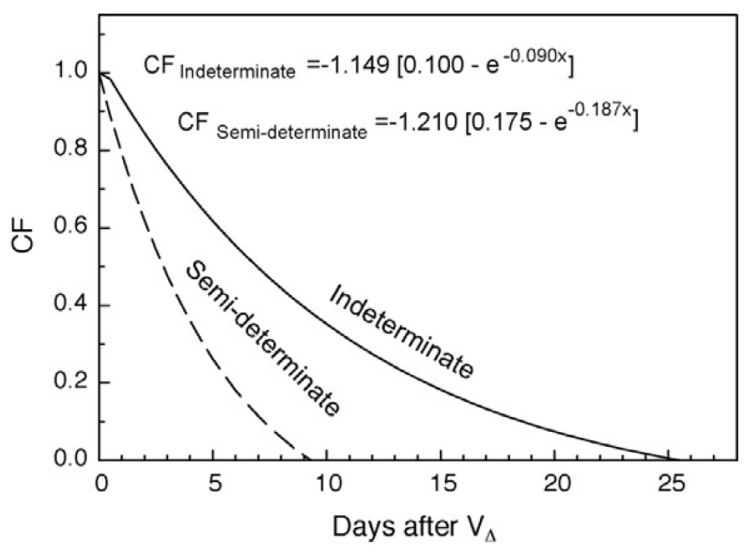

Figure 2. Chronological function (CF) used in simulation of soybean V-stages (Equation (6)). $x$, day after $\mathrm{V}_{\Delta}$. 
Accumulated values of the daily developmental rate are used to determine the occurrence of unifoliate $\left(\mathrm{V}_{1}\right)$, floral induced $\left(\mathrm{R}_{0}\right)$, first open flower $\left(\mathrm{R}_{1}\right)$, beginning seed $\left(\mathrm{R}_{5}\right)$, and physiological maturity $\left(\mathrm{R}_{7}\right)$. The daily development rate $(r)$ was calculated with the following relationship:

$$
r=R_{\max } f(T) f(P)
$$

where $R_{\max }$ is the maximum development rate $\left(\mathrm{day}^{-1}\right)$ at optimum temperature and photoperiod, $f(T)$ the temperature function, and $f(P)$ is the photoperiod function. For developmental phases that were not sensitive to temperature or photoperiod, the temperature or photoperiod function, respectively, equaled one (Figure 1).

The temperature response, $f(T)$, in SOYDEV was based on a non-linear beta function, the version used in Wang and Engel (1998) with appropriate cardinal temperatures for each phase as shown in Table 2:

$f(T)=\frac{2\left(T-T_{\min }\right)^{\alpha}\left(T_{\mathrm{opt}}-T_{\min }\right)^{\alpha}-\left(T-T_{\min }\right)^{2^{\alpha}}}{\left(T_{\mathrm{opt}}-T_{\min }\right)^{2 \alpha}}$

if $T_{\min }<T<T_{\max }, \quad \alpha=\frac{\ln (2)}{\ln \left[T_{\max }-T_{\min } / T_{\mathrm{opt}}-T_{\min }\right]}$

$f(T)=0$ if $T \geq T_{\max }$ or $T \leq T_{\min }$

where for a given phase, $T_{\max }$ is the temperature above which the development rate is zero $\left({ }^{\circ} \mathrm{C}\right), T_{\min }$ is the temperature below which the development rate is zero $\left({ }^{\circ} \mathrm{C}\right), T_{\text {opt }}$ is the temperature at which the development rate is optimal $\left({ }^{\circ} \mathrm{C}\right), \alpha$ is the beta function shape factor and $T$ is the mean daily temperature $\left({ }^{\circ} \mathrm{C}\right)$. The temperature response for the emergence to unifoliate sub-phase is shown in Figure 3 as compared with the linear function used in CROPGRO.

The photoperiod response in SOYDEV was based on a non-linear beta function, modified from the version described in Yin et al. (1995) with the cardinal daylength for each phase as shown in Table 2:

$$
\begin{aligned}
& f(P)=\left[\left(\frac{P-P_{\mathrm{opt}}}{m}+1\right)\left(\frac{P_{\mathrm{crt}}-P}{P_{\mathrm{crt}}-P_{\mathrm{opt}}}\right)^{\left(P_{\mathrm{crt}}-P_{\mathrm{opt}}\right) / m}\right]^{\alpha} \\
& \text { if } P_{\mathrm{opt}} \leq P \leq P_{\mathrm{crt}}, \quad \alpha=\frac{\ln [2]}{\ln \left[\left(\left(P_{\mathrm{crt}}-P_{\mathrm{opt}}\right) / m\right)+1\right]} \\
& f(P)=0 \text { if } P>P_{\mathrm{crt}}, \quad f(P)=1 \text { if } P<P_{\mathrm{opt}}
\end{aligned}
$$

where for a given phase, $P_{\mathrm{crt}}$ is the daylength above which development rate is zero (h), $P_{\text {opt }}$ is the daylength below which development rate is optimum (h), $P$ is the daylength (based on $-6.00^{\circ}$ and $-0.83^{\circ}$ solar elevation angle for floral induction and post-flowering photoperiod responses, respectively) and $m$ is the constant $(3.0 \mathrm{~h})$.

Main stem node appearance rate $\left(r_{\mathrm{NA}}\right)$ after unifoliate stage was accumulated to simulate the subsequent $\mathrm{V}$-stages and was calculated by the following equation:

$$
\begin{aligned}
& r_{\mathrm{NA}}=r_{\mathrm{NA}, \max } f(T) \mathrm{CF} \\
& \mathrm{CF}=-A\left(B-\mathrm{e}^{-C x}\right)
\end{aligned}
$$

where $r_{\mathrm{NA}}$ is the main stem node appearance rate (node day ${ }^{-1}$ ), $r_{\mathrm{NA}, \max }$ is the maximum main stem node appearance rate (node day $^{-1}$ ), CF is the chronological function for reduction of main stem node appearance rate, $x$ is the days after $\mathrm{V}_{\Delta}$ (the onset of reduction in main stem node appearance rate), and $A, B, C$ are the chronology function coefficients. The values of chronology coefficients $A, B$, and $C$ for indeterminate and semideterminate cultivars were 1.149, $0.1,0.09$, and 1.210, 0.175, 0.187 , respectively (Figure 2 ). These chronology coefficients were derived from node appearance data of cv. NE3001 (semi-

\begin{tabular}{|c|c|c|c|c|c|c|c|c|}
\hline Phase & $T_{\min }\left({ }^{\circ} \mathrm{C}\right)$ & $T_{\mathrm{opt}}\left({ }^{\circ} \mathrm{C}\right)$ & $T_{\max }\left({ }^{\circ} \mathrm{C}\right)$ & $P_{\text {opt }}(\mathrm{h})$ & $B\left({ }^{\circ}\right)$ & $R_{\max }\left(\right.$ day $\left.^{-1}\right)$ & & \\
\hline Emergence- $V_{1}$ & $5.0 \mathrm{~A}$ & & $31.5 \mathrm{~A}$ & $45.0 \mathrm{~A}$ & - & - & - & $0.1194 \mathrm{E}$ \\
\hline Emergence- $\mathrm{V}_{0}{ }^{\mathrm{a}}$ & $5.0 \mathrm{~A}$ & & $31.5 \mathrm{~A}$ & $45.0 \mathrm{~A}$ & - & - & - & $0.1990 \mathrm{E}$ \\
\hline $\mathrm{V}_{1}-\mathrm{V}_{n}$ & $7.6 \mathrm{E}$ & & $31.0 \mathrm{~A}$ & $40.0 \mathrm{E}$ & - & - & - & $0.4520 \mathrm{E}$ \\
\hline $\mathrm{V}_{0}-\mathrm{R}_{0}$ & - & & - & - & $11 \mathrm{C}$ & $25 \mathrm{C}$ & -6.00 & $0.2500 \mathrm{D}$ \\
\hline $\mathrm{R}_{0}-\mathrm{R}_{1}$ & $7.0 \mathrm{~A}$ & & $32.4 \mathrm{~A}$ & $41.9 \mathrm{~A}$ & - & - & - & $0.0738 \mathrm{E}$ \\
\hline $\mathrm{R}_{1}-\mathrm{R}_{5}$ & $3.6 \mathrm{E}$ & & $25.0 \mathrm{~B}$ & $40.0 \mathrm{E}$ & $12 \mathrm{E}$ & $18 \mathrm{E}$ & -0.83 & $0.0483 \mathrm{E}$ \\
\hline $\mathrm{R}_{1}-\mathrm{R}_{3.5}^{\mathrm{a}}$ & $3.6 \mathrm{E}$ & & $25.0 \mathrm{~B}$ & $40.0 \mathrm{E}$ & $12 \mathrm{E}$ & $18 \mathrm{E}$ & -0.83 & $0.0790 \mathrm{E}$ \\
\hline $\mathrm{R}_{1}-\mathrm{V}_{\Delta}^{\mathrm{a}}$ & $3.6 \mathrm{E}$ & & $25.0 \mathrm{~B}$ & $40.0 \mathrm{E}$ & $12 \mathrm{E}$ & $18 \mathrm{E}$ & -0.83 & $0.0690 \mathrm{E}$ \\
\hline $\mathrm{R}_{1}-\mathrm{R}_{7}$ & $0.0 \mathrm{E}$ & & $21.5 \mathrm{E}$ & $38.7 \mathrm{E}$ & $12 \mathrm{E}$ & $18 \mathrm{E}$ & -0.83 & $0.0168 \mathrm{E}$ \\
\hline
\end{tabular}
determinate, MG 3.0) and cv. Pioneer P93M11 (indeterminate, MG 3.1) in the 2005 growing season. Daily main stem node appearance rate was first estimated by plotting $\mathrm{V}$-stage data on day of year. The day when the estimated node appearance rate

Table 2. Cardinal temperatures and photoperiods, and cultivar-specific parameters (MG 3.0, semi-determinate) used in SOYDEV

${ }^{a}$ Mid-phase was simulated using mid-phase coefficients $\left(0.60\right.$ for emergence- $\mathrm{V}_{0}, 0.613$ for $\mathrm{R}_{1}-\mathrm{R}_{3.5}, 0.704$ for $\left.\mathrm{R}_{1}-\mathrm{V}_{\Delta}\right)$. Cardinal temperatures and daylengths for a mid-phase were the same as the corresponding main or sub-phase. $R_{\max }$ for a mid-phase equaled to $R_{\max }$ of the corresponding main or sub-phase divided by the mid-phase coefficient. $\mathrm{V}_{1}$, unifoliate stage; $\mathrm{V}_{0}$, cotyledon stage; $\mathrm{V}_{n}$, end of main stem node appearance; $\mathrm{R}_{0}$, end of floral induction; $\mathrm{R}_{1}$, first open flower; $\mathrm{R}_{5}$, beginning seed; $\mathrm{V}_{\Delta}$, beginning of the reduction in main stem node appearance rate; $\mathrm{R}_{7}$, physiological maturity. $T_{\max }$, temperature above which the development rate is zero $\left({ }^{\circ} \mathrm{C}\right) ; T_{\min }$, temperature below which the development rate is zero $\left({ }^{\circ} \mathrm{C}\right) ; T_{\text {opt}}$, temperature at which the development rate is optimal $\left({ }^{\circ} \mathrm{C}\right) ; P_{\text {crt }}$, photoperiod above which development rate is zero (h); $P_{\text {opt }}$, photoperiod below which development rate is optimal (h); $B$, solar elevation angle $\left({ }^{\circ}\right)$. Letters after the parameters values indicate the source of estimation: (A) Hesketh et al. (1973), (B) Brown and Chapman (1960), (C) Cregan and Hartwig (1984), (D) Taiz and Zeiger (1991), and (E) Field data (2004). 


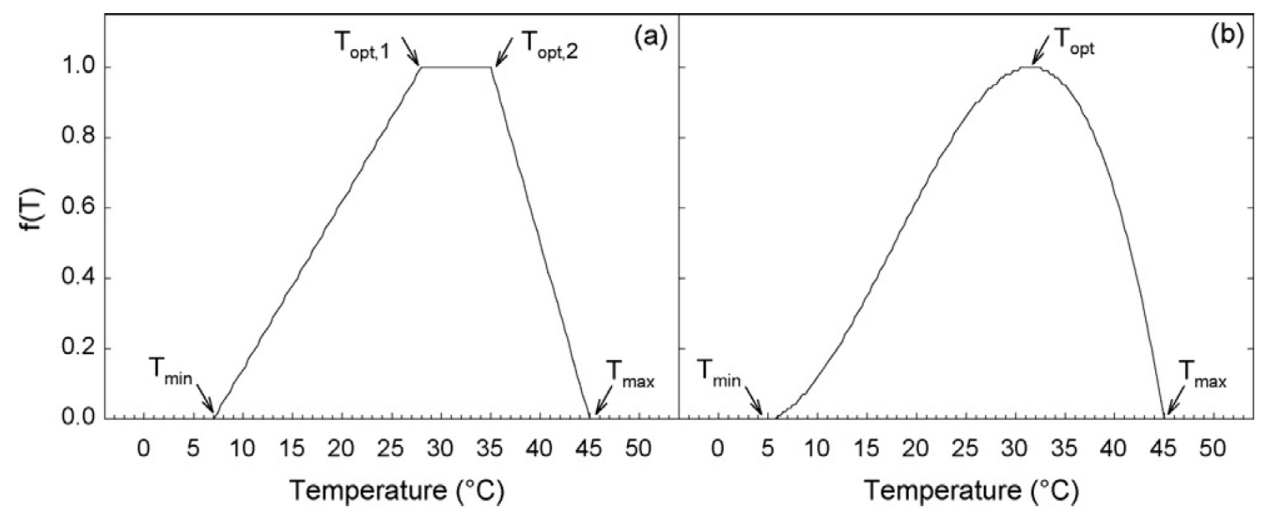

Figure 3. Temperature functions describing soybean development rate towards the appearance of the unifoliate stage $\left(\mathrm{V}_{1}\right)$. (a) Linear spline function (Jones et al., 2000) used in CROPGRO $\left(T_{\min }=7^{\circ} \mathrm{C}, T_{\mathrm{opt}, 1}=28^{\circ} \mathrm{C}, T_{\mathrm{opt}, 2}=35^{\circ} \mathrm{C}\right.$, and $T_{\max }=45^{\circ} \mathrm{C}$ ). (b) Beta function (Wang and Engel, 1998) used in SOYDEV $\left(T_{\text {min }}=5^{\circ} \mathrm{C}, T_{\mathrm{opt}}=31.5^{\circ} \mathrm{C}\right.$, and $\left.T_{\max }=45^{\circ} \mathrm{C}\right)$.

was reduced from its optimal value was noted as $\mathrm{V}_{\Delta}$. CF was calculated as ratio of the current day main stem node appearance rate and the optimal node appearance rate. $\mathrm{V}_{\Delta}$ was associated with the reproductive phase $R_{1}-R_{5}$ (Figure $1 d$ ).

\subsection{Model evaluation}

For model evaluation, simulated occurrences of phenological stages (day of year) and cumulative number of main stem nodes above the cotyledon node $\left(\mathrm{V}_{0}\right)$ were compared with the observed values. The statistics used to evaluate model performance were the root mean square error (RMSE) and the normalized root mean square error (NRMSE), calculated as (Janssen and Heuberger, 1995):

$$
\begin{aligned}
& \text { RMSE }=\sqrt{\frac{\sum\left(s_{i}-o_{i}\right)^{2}}{n}} \\
& \mathrm{NRMSE}=\frac{\sqrt{\sum\left(s_{i}-o_{i}\right)^{2} / n}}{\sum o_{i} / n}
\end{aligned}
$$

where $s$ is the simulated data on the $i$ th day, $o$ is the observed data on the ith day, and $n$ is the number of pairs of simulated and observed data. The smaller the RMSE and NRMSE, the better the simulation. SOYDEV performance will be compared to a widely used soybean model, CROPGRO (Jones et al., 2000). The CROPGRO model was chosen because it shares overall similarity with SOYDEV in the use of a multiplicative approach. This approach allows different temperature and photoperiod functions and steps in the simulation of flowering between the two models to be compared.

To evaluate model sensitivity to the availability of cultivar-specific input parameters, simulations of phenological stages with SOYDEV were made for all 14 cultivars $\times 4$ sowing dates in 2004 and 8 cultivars $\times 3$ sowing dates in 2005 . These data sets include the calibration data set from each year, the first sowing date in 2004 and the second sowing date in 2005. The reason the calibration data set were included was to include the optimum conditions, otherwise the results would be biased to non-optimum conditions associated sowing dates.
Four simulation options were evaluated: (a) cultivar-specific parameters derived from full calibration wherein each cultivar had a set of unique coefficients, (b) no cultivar-specific parameters, one set of coefficients for all cultivars, (c) $R_{\max }{ }^{-}$ cultivar-specific parameters derived from maturity group and stem termination type, and (d) photoperiod-cultivar-specific model parameters derived from maturity group and stem termination type. In options (c) and (d), selected model parameters were derived based on their relationships with published maturity group ratings, which is the only widely available cultivar information associated with phenology provided by seed producers in North America.

When two soybean genotypes are exposed to the same temperature and photoperiod, differences in development rates can be simulated by using either different $R_{\max }$ or different photoperiod response parameters. Correlation analyses were conducted evaluating $R_{\max }$ in (c) or photoperiod response

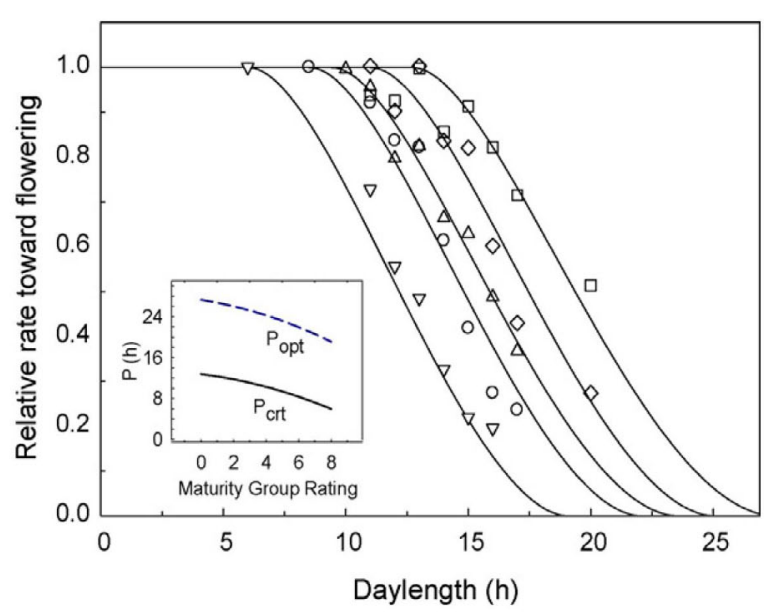

Figure 4. Simulated and observed photoperiod response of the development rate toward flowering: $(\square),(\diamond),(\Delta),(0)$, and $(\nabla)$, indicate observed data from Cregan and Hartwig (1984) for MG 0, 3, 5, 6, and 8, respectively. Lines indicate simulated rate toward flowering for each of the maturity group ratings (MG) using beta function derived from Yin et al. (1995). Simulation is based on generalized parameters shown in the insert, where $P_{\text {opt }}$ (optimum daylength) $=12.759-0.388 \mathrm{MG}-0.058 \mathrm{MG}^{2}$, and $P_{\text {crt }}$ (critical daylength) $=27.275-0.493 \mathrm{MG}-0.066 \mathrm{MG}^{2}$. 
parameters in (d) against maturity group ratings, holding photoperiod response parameters in (c) or $R_{\max }$ in (d) constant for all cultivars for all cultivars in the first sowing date in 2004 and the second sowing date in 2005. The effect of stem termination types (semi-determinate and indeterminate) on $R_{\max }$ or photoperiod response parameters was also evaluated. Equations relating $P_{\text {crt }}$ and $P_{\text {opt }}$ for the floral induction phase $\left(\mathrm{V}_{0}-\right.$ $\mathrm{R}_{0}$ ) with maturity group rating were derived from our evaluation of data published by Cregan and Hartwig (1984) (Figure 4) and were used in option (c).

Cultivar-specific parameters were used in SOYDEV to simulate phenology for the year $\times$ sowing date combinations that were not included in the calibration (the second to the fourth sowing dates in 2004 and the first and the third sowing dates in 2005). This approach represents the most detailed of the model simulations, but it requires observed data for calibrating each of the cultivars of interest. In practical applications, such data are often not available and commercial soybean cultivars change frequently. Therefore, options (b)-(d) were tested as possible alternatives for simulating soybean phenology without the need for cultivar-specific calibration. In the non-calibrated option (b), the model was run using the same default parameters (Table 2) for each of the cultivars shown in Table 1.

\section{Results}

\subsection{Simulation of soybean phenology in the high-yield long- term experiment}

Soybean yields, occurrences and duration of reproductive stages of cv. NE3001 (MG 3.0, semi-determinate) grown in the long-term experiment at Lincoln, NE are shown in Table 3. The highest yield (5.9 Mg ha-1) was achieved in the 2001 growing season when both flowering (emergence- $R_{1}$ ) and post-flowering $\left(\mathrm{R}_{1}-\mathrm{R}_{7}\right)$ durations were the longest. The flowering duration (emergence- $\mathrm{R}_{1}$ ) was negatively correlated with mean temperature $(r=-0.83, p<0.1)$ and minimum daylength $(r=-0.85, p<0.1)$, but no correlation was evident between post-flowering duration and mean temperature, maximum daylength, or minimum daylength (data not shown).

Table 3. Overview of phenological occurrence, duration, and seed yield of soybean cv. NE3001 (MG 3.0, semi-determinate) in the long-term high-yield experiment at Lincoln, NE

\begin{tabular}{|c|c|c|c|c|c|c|}
\hline \multirow[t]{2}{*}{ Year } & \multicolumn{3}{|c|}{ Occurrence (day of year) } & \multicolumn{2}{|c|}{ Duration (days) } & \multirow{2}{*}{$\begin{array}{c}\text { Yield } \\
(13 \% \text { m.c. }) \\
\left(\mathrm{Mg} \mathrm{ha}^{-1}\right)\end{array}$} \\
\hline & Emergence & $\mathrm{R}_{1}$ & $\mathrm{R}_{7}$ & Emergence- $\mathrm{R}_{1}$ & $\mathrm{R}_{1}-\mathrm{R}_{7}$ & \\
\hline 1999 & 136 & 175 & 252 & 39 & 77 & $5.02 \pm 0.18$ \\
\hline 2000 & 134 & 170 & 248 & 36 & 78 & $4.28 \pm 0.18$ \\
\hline 2001 & 125 & 169 & 255 & 44 & 86 & $5.90 \pm 0.05$ \\
\hline 2002 & 140 & 176 & 252 & 36 & 76 & $5.26 \pm 0.14$ \\
\hline 2004 & 131 & 174 & 250 & 43 & 76 & $4.99 \pm 0.14$ \\
\hline 2005 & 130 & 171 & 249 & 41 & 78 & $4.51 \pm 0.20$ \\
\hline
\end{tabular}

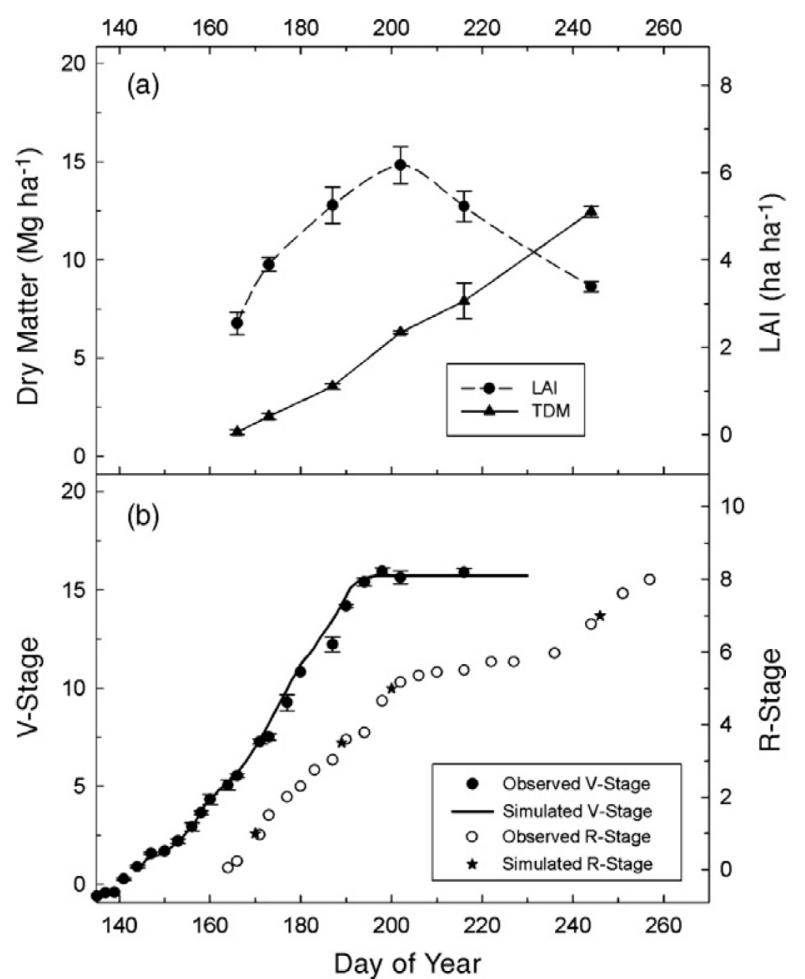

Figure 5. Growth and development of the semi-determinate soybean cv. NE3001 in the high-yield experiment in 2005. (a) Total above ground dry matter and leaf area index (LAI). (b) Vegetative and reproductive stages (Fehr and Caviness, 1977) as observed and simulated with SOYDEV. Bars indicate standard errors associated with dry matter, leaf area index, and Vstages measurements.

An example of the relationship between observed phenology and growth (LAI and total above ground dry mater) of soybean cv. NE3001 in 2005 growing season is illustrated in Figure 5. Leaf area index reached a maximum $(6.2 \pm 0.42)$ between $R_{3.5}$ and $R_{5}$ when vegetative growth was approaching its peak value, while total above ground dry matter was at maximum as the plant approached $R_{7}$. SOYDEV, calibrated with data from the 2004 growing season, accurately simulated the pattern of vegetative development, final main stem node number, and the occurrence of key R-stages for the 2005 independent data set (Figure $5 b$ ).

A summary of 6 years of phenology simulation in the longterm high-yield experiment comparing results from SOYDEV with CROPGRO is shown in Figure 6. Overall RMSE of simulating unifoliate, $\mathrm{R}_{1}, \mathrm{R}_{3 / 3.5}, \mathrm{R}_{5}$, and $\mathrm{R}_{7}$ stages was 1.8 days with SOYDEV as compared to 2.9 days with CROPGRO. The improvement in simulating $\mathrm{V}_{1}$ between the simulation models was smallest (0.2 day), indicating that the choice of linear versus nonlinear temperature functions may not be crucial for simulating very early soybean development. The ability to simulate $\mathrm{R}_{1}$ is particularly important because this stage serves as the starting point for simulation of subsequent reproductive stages and simulation of pod set and seed filling (Figure 1). SOYDEV simulated $R_{1}$ in cv. NE3001 with an across years RMSE of 1.8 days, as compared to 2.6 days in CROPGRO. Across years and stages, improvements in simulation of the different R-stages ranged from 0.2 to 1.6 days (Figure 6). 


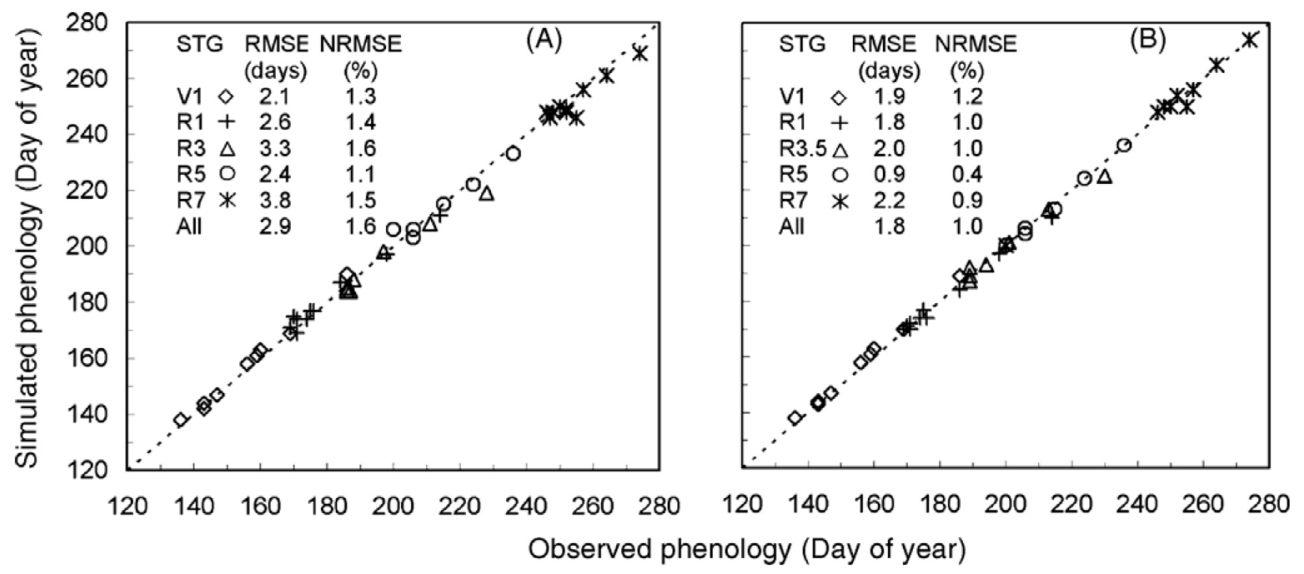

Figure 6. Observed and simulated soybean phenology with CROPGRO (A) and SOYDEV (B) for NE3001 in the high-yield experiment in Lincoln, Nebraska (1999-2002, 2004, and 2005). The simulation for both models utilized cultivar-specific parameters calibrated against phenology in the 2004 growing season for cv. NE3001 (MG 3.0, semi-determinate). Different symbols indicate phenology for different developmental stages as indicated in the legend. Shown in the legend are also root mean square error (RMSE) and its normalized value (NRMSE) associated with simulation of each of the developmental stages.

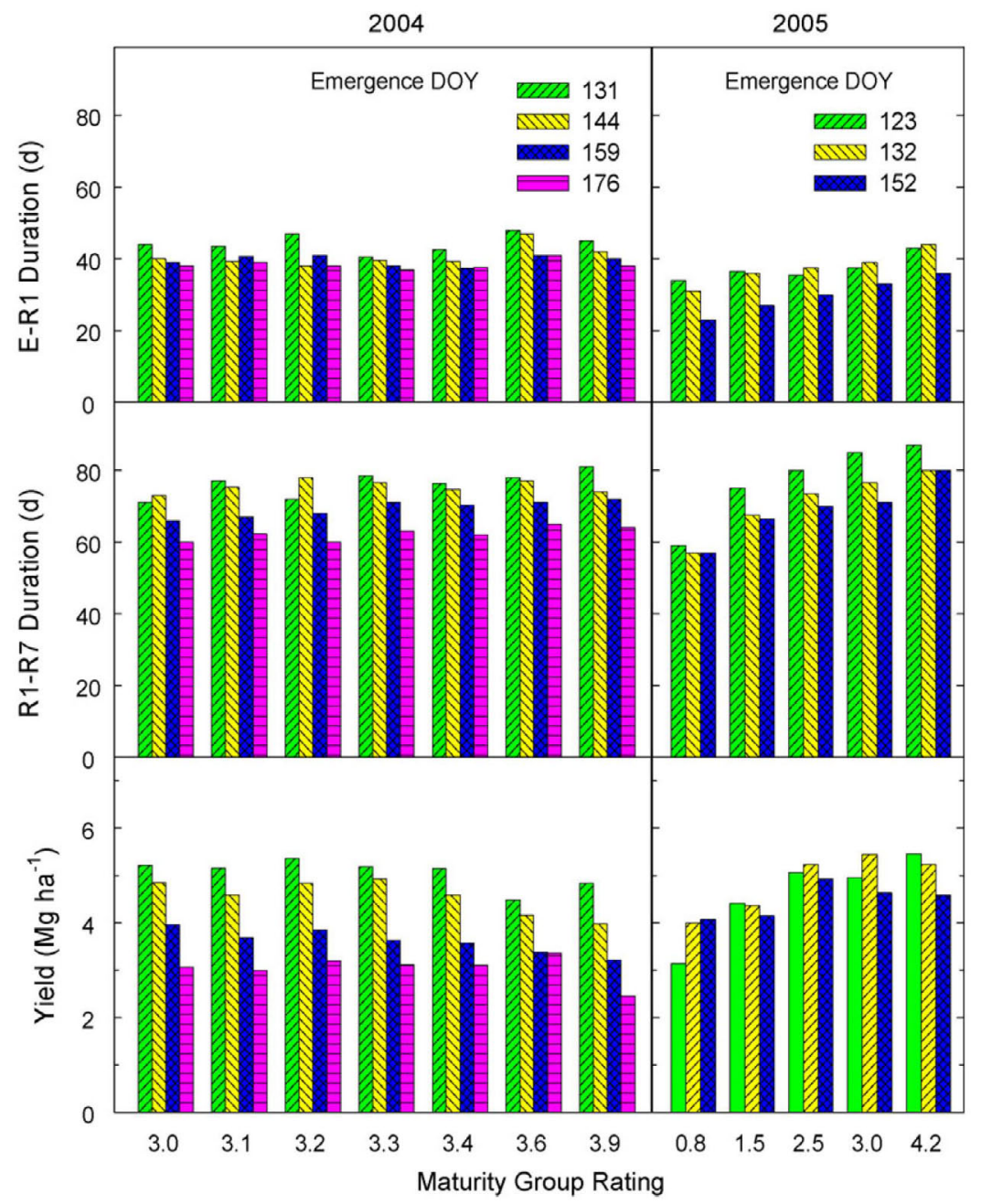

Figure 7. Pre- (emergence- $\left.\mathrm{R}_{1}\right)$ and post-flowering $\left(\mathrm{R}_{1}-\mathrm{R}_{7}\right)$ duration and seed yield of soybean cultivars with different maturity group rating in the cultivar $\times$ sowing date experiment in 2004 and 2005 at Lincoln, NE. Numbers in the legend indicate emergence (day of year). See Table 1 for cultivar names and their maturity group ratings. 


\subsection{Simulation of soybean phenology in the cultivar $\times$ sowing date experiment}

In the cultivar $\times$ sowing date experiment, the duration of preflowering (emergence- $\left.\mathrm{R}_{1}\right)$ and post-flowering $\left(\mathrm{R}_{1}-\mathrm{R}_{7}\right)$ phases, as well as seed yields generally decreased with later sowing in both years within maturity groups (Figure 7). Soybean cultivars from higher maturity groups tended to have longer postflowering phase, but only slightly longer pre-flowering duration (Figure 7). The increase in duration with later maturity group was greatest for earlier planting date for the post-flowering phase. In contrast, the increase in duration with later maturity group was greatest for the later planting date for the preflowering phase.

SOYDEV provided accurate simulation of the patterns of vegetative development and the final number of main stem nodes for all cultivars in the planting date study (Figure 8). Late planted soybeans developed less main stem nodes than early planted soybeans. Final main stem node number was positively correlated with duration of $\mathrm{R}_{1}-\mathrm{R}_{5}$ as indicated from the 2004 cultivar $\times$ sowing date study based on the actual measured values (Figure 9a). This correlation between final node number and duration of $R_{1}-R_{5}$ was simulated relatively well by SOYDEV (Figure 9b). Across all cultivars tested, the RMSE of V-stages simulation was 0.7 nodes in 2004 and 0.5 nodes in 2005 (Table 4). Across cultivar and sowing date, the RMSE of V-stages simulation was 1.0 days and 0.8 days in 2004 and 2005, respectively (data not shown).

RMSE values with respect to simulation of unifoliate $\left(\mathrm{V}_{1}\right)$ and key reproductive stages $\left(\mathrm{R}_{1}, \mathrm{R}_{3.5}, \mathrm{R}_{5}\right.$, and $\left.\mathrm{R}_{7}\right)$ with SOYDEV in the cultivar $\times$ sowing date experiment for the fully calibrated option are shown in Figure 10a. Across stages and

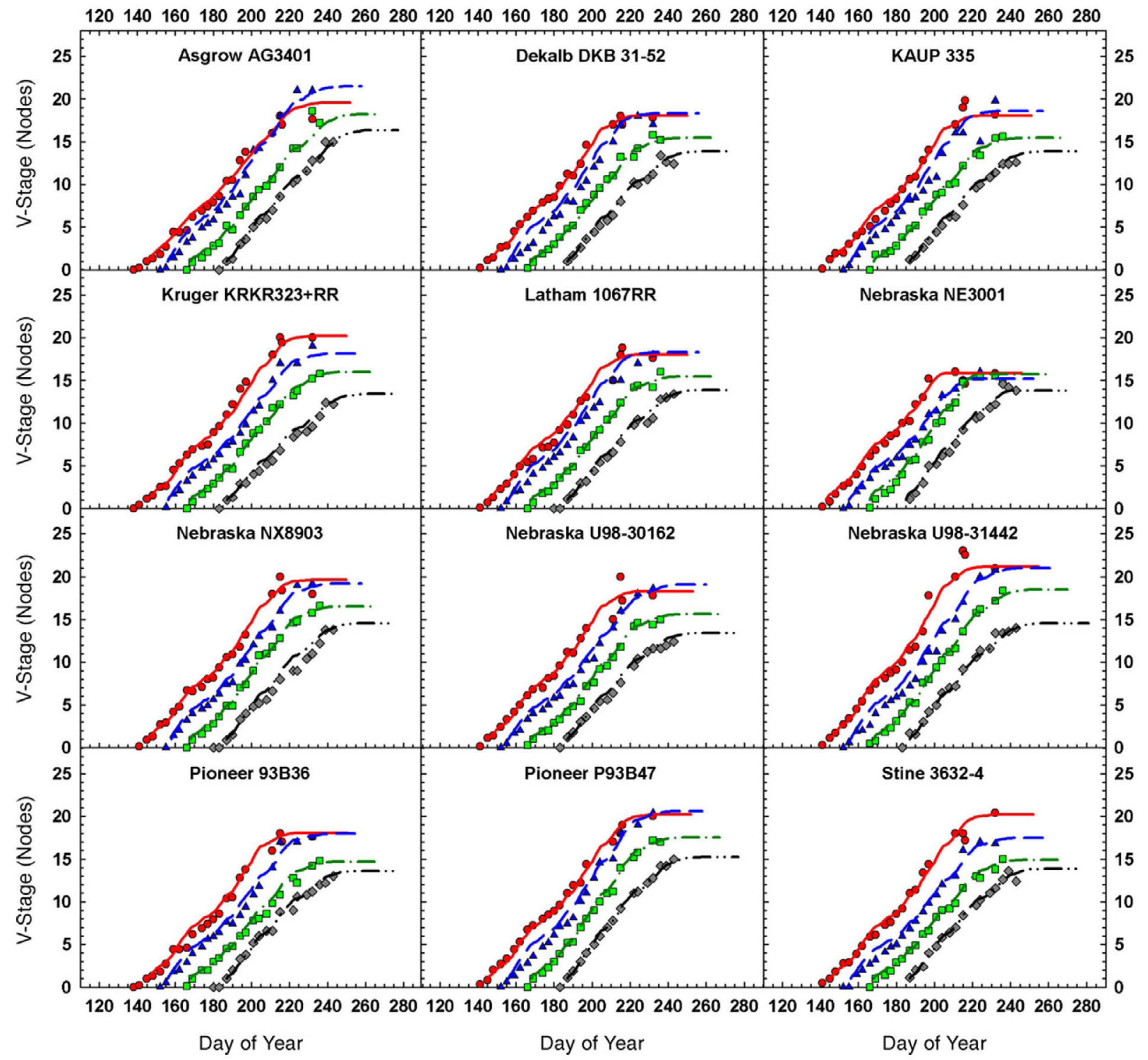

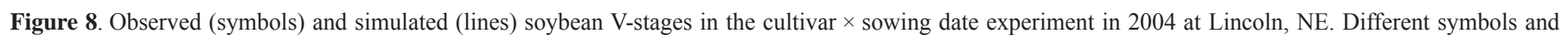

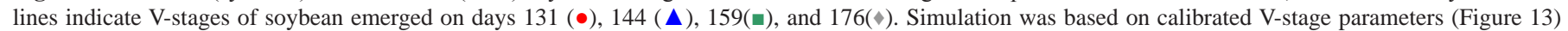
and $R_{\max }$-cultivar-specific parameters derived from maturity group rating (Figure 11). See Table 1 for maturity group ratings of the above cultivars. 


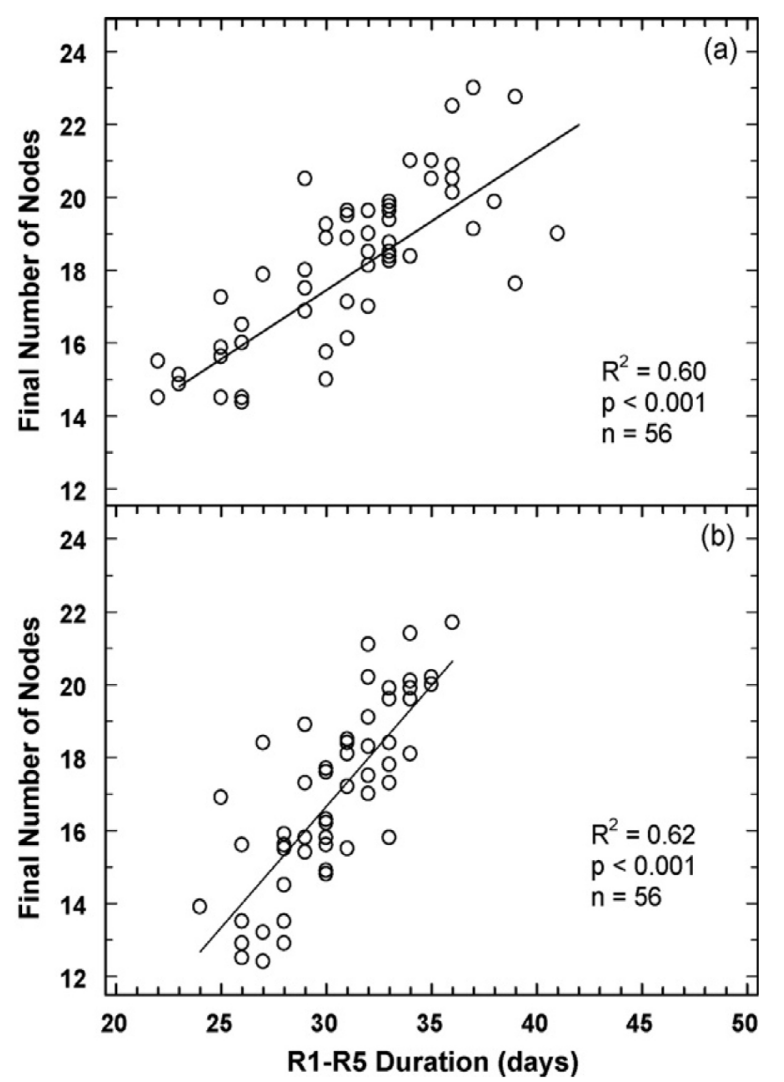

Figure 9. Final number of main stem nodes and $R_{1}-R_{5}$ duration in the cultivar $\times$ sowing date experiment in 2004 as observed (a) and simulated (b). $n$ is the number of observation.

years, the RMSE was 3.3 days (3.2 days and 3.6 days in 2004 and 2005, respectively) (Figure 10a). In both years RMSE values were relatively higher for mid-pod $\left(\mathrm{R}_{3.5}\right)$ and beginning seed $\left(\mathrm{R}_{5}\right)$ stages (4.3 and 4.0 days, respectively) and smallest for $V_{1}$ and $R_{1}$ (1.7 and 2.7 days, respectively, Figure 10a).

\subsection{Simulation of soybean phenology without cultivar- specific model calibration}

Phenology simulation shown in Figure 10a was based on fullcalibration of cultivar-specific parameters for all 21 cultivars used in the cultivar $\times$ sowing date experiment. A considerable decrease in RMSE was evident when the least input-demanding option (non-calibrated option) was used (Figure 10b), in which the generic set of model parameters (Table 2) was applied to all 21 cultivars. The overall RMSE of the simulated phenological stages were 5.8 days and 9.3 days in 2004 and 2005 , respectively. The RMSE value was greater in 2005 than in 2004 due to a wider range of cultivars used (MG 0.8-4.2) in 2005.

Significant correlations were found between maturity group rating and $R_{\max }$ during the floral induction phase $\left(\mathrm{R}_{0}-\mathrm{R}_{1}\right.$, Figure 11a), pod and seed set duration $\left(R_{1}-R_{5}\right.$, Figure 11c), and post-flowering duration $\left(\mathrm{R}_{1}-\mathrm{R}_{7}\right.$, Figure $\left.11 \mathrm{~d}\right)$. Similarly, empirical relationships allowed estimating $R_{\max }$ associated with photoperiod response in the floral induction process $\left(\mathrm{V}_{0}-\mathrm{R}_{0}\right)$ and $P_{\text {crt }}$ and $P_{\text {opt }}$ for the $\mathrm{R}_{1}-\mathrm{R}_{5}$ and $\mathrm{R}_{1}-\mathrm{R}_{7}$ periods from published
Table 4. Root mean square error (RMSE) of V-stage simulation with SOYDEV in the cultivar $\times$ sowing date experiment at Lincoln, NE, in 2004 and 2005

\begin{tabular}{|c|c|c|c|c|c|}
\hline \multirow[t]{2}{*}{ Cultivar } & \multicolumn{4}{|c|}{ Emergence (day of year) ${ }^{a}$} & \multirow[b]{2}{*}{ All dates } \\
\hline & 131 & 144 & 159 & 176 & \\
\hline \multicolumn{6}{|l|}{ Year 2004} \\
\hline Asgrow AG3401 & 0.8 & 1.2 & 0.9 & 0.4 & 0.9 \\
\hline Dekalb DKB 31-52 & 0.4 & 0.8 & 0.5 & 0.5 & 0.6 \\
\hline KAUP 335 & 0.7 & 1.0 & 0.4 & 0.5 & 0.7 \\
\hline Kruger KR323+ RR & 0.5 & 1.2 & 0.5 & 0.5 & 0.8 \\
\hline Latham 1067RR & 1.5 & 1.0 & 0.4 & 0.7 & 1.0 \\
\hline Nebraska NE3001 & 0.5 & 0.8 & 0.6 & 0.9 & 0.8 \\
\hline Nebraska NE3201 & 1.0 & 1.0 & 0.5 & 0.4 & 0.8 \\
\hline Nebraska NEX8903 & 0.7 & 0.9 & 0.5 & 0.4 & 0.7 \\
\hline Nebraska U98-307162 & 0.8 & 1.2 & 0.3 & 0.4 & 0.7 \\
\hline Nebraska U98-307917 & 0.6 & 1.2 & 0.5 & 0.5 & 0.6 \\
\hline Nebraska U98-311442 & 1.0 & 0.9 & 0.4 & 0.5 & 0.8 \\
\hline Pioneer 93B36 & 0.7 & 0.8 & 0.6 & 0.4 & 0.7 \\
\hline Pioneer 93B47 & 0.5 & 1.0 & 0.4 & 0.2 & 0.6 \\
\hline Stine 3632-4 & 0.6 & 0.8 & 0.4 & 0.4 & 0.6 \\
\hline Across cultivars & 0.8 & 1.0 & 0.5 & 0.5 & 0.7 \\
\hline Range & 1.1 & 0.5 & 0.5 & 0.7 & 0.4 \\
\hline \multirow[t]{2}{*}{ Cultivar } & \multicolumn{5}{|c|}{ Emergence (day of year) ${ }^{\mathrm{a}}$} \\
\hline & 123 & 132 & 152 & & dates \\
\hline \multicolumn{6}{|l|}{ Year 2005} \\
\hline Asgrow AG0801 & 0.6 & 0.5 & 0.4 & & 0.5 \\
\hline Dekalb DKB 1552 & 0.4 & 0.3 & 0.4 & & 0.4 \\
\hline Nebraska U01-290401 & 0.5 & 0.4 & 0.4 & & 0.4 \\
\hline Nebraska U01-390224 & 0.3 & 0.4 & 0.6 & & 0.4 \\
\hline Dekalb DKB 2653 & 0.9 & 0.6 & 1.0 & & 0.8 \\
\hline Nebraska NE3001 & 0.4 & 0.4 & 0.5 & & 0.4 \\
\hline Pioneer 93M11 & 0.4 & 0.7 & 0.8 & & 0.6 \\
\hline Dekalb DKB 4251 & 0.4 & 0.6 & 0.6 & & 0.5 \\
\hline Across cultivars & 0.5 & 0.5 & 0.6 & & 0.5 \\
\hline Range & 0.5 & 0.3 & 0.6 & & 0.5 \\
\hline
\end{tabular}

${ }^{a}$ RMSE (nodes).

MG ratings (Figure 12). No significant correlation was observed between maturity group rating and the $\mathrm{R}_{3.5}$ stage indicator and thus an average value of 0.6123 was assumed (Figure 11b). No significant effect of stem termination type on $R_{\max }$ or photoperiod response parameters was observed in reproductive phases. Unlike reproductive phases, no relationship was observed between maturity group rating and the parameters for simulating main stem node appearance. The parameters $r_{\mathrm{NA} \text {,max }}$ and $\mathrm{V}_{\Delta}$ were instead influenced by the stem termination types and sowing date treatments. To account for the effect of sowing date and thus time of emergence, $r_{\mathrm{NA}, \max }$ and $\mathrm{V}_{\Delta}$ values (obtained by calibration against observed data in 2004 and 2005) were plotted against daylength at the time of emergence (Figure 13). With the exception of semi-determinate type, the effect of late sowing (early June or later) was associated with reduction in $r_{\mathrm{NA} \text {, max }}$ and $\mathrm{V}_{\Delta}$. In general, using the above simplification approach for deriving cultivar-specific parameters from maturity group rating resulted in only a small loss of simulation accuracy in term of RMSE values 


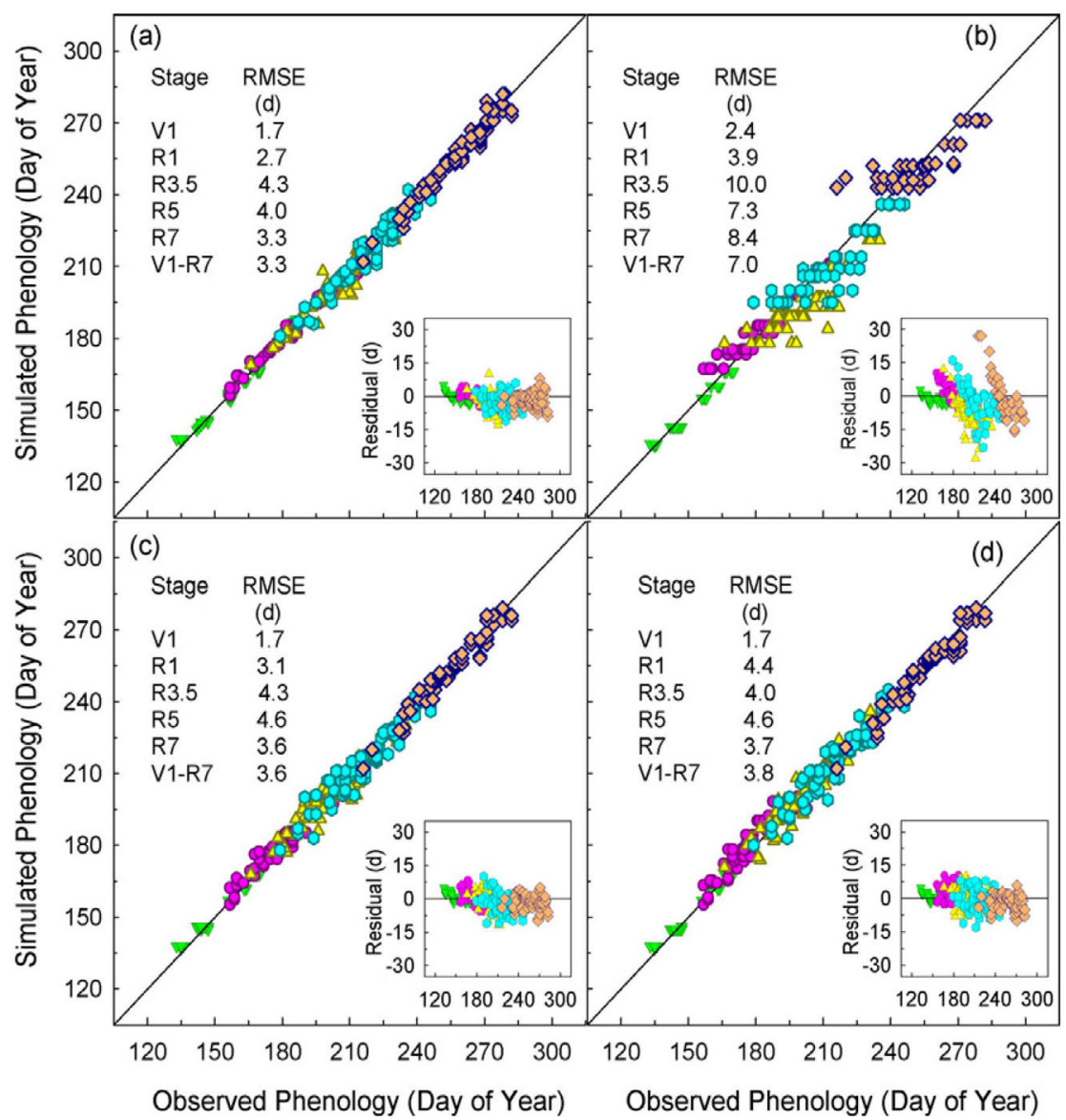

Figure 10. Observed and simulated soybean phenology with SOYDEV in the cultivar $\times$ sowing date experiment in 2004 and 2005 using full calibrated (a), non-calibrated (b), $R_{\max }$-based generalized (c), and photoperiod-response-based generalized (d) modes. Symbols indicate phenological stages: $V_{1}(\nabla)$, $R_{1}(\bullet)$, $\mathrm{R}_{3.5}(\triangle), \mathrm{R}_{5}(\bullet)$, and $\mathrm{R}_{7}(\bullet)$. Shown in the insets are plots of residuals (simulated - observed) versus observed phenology.

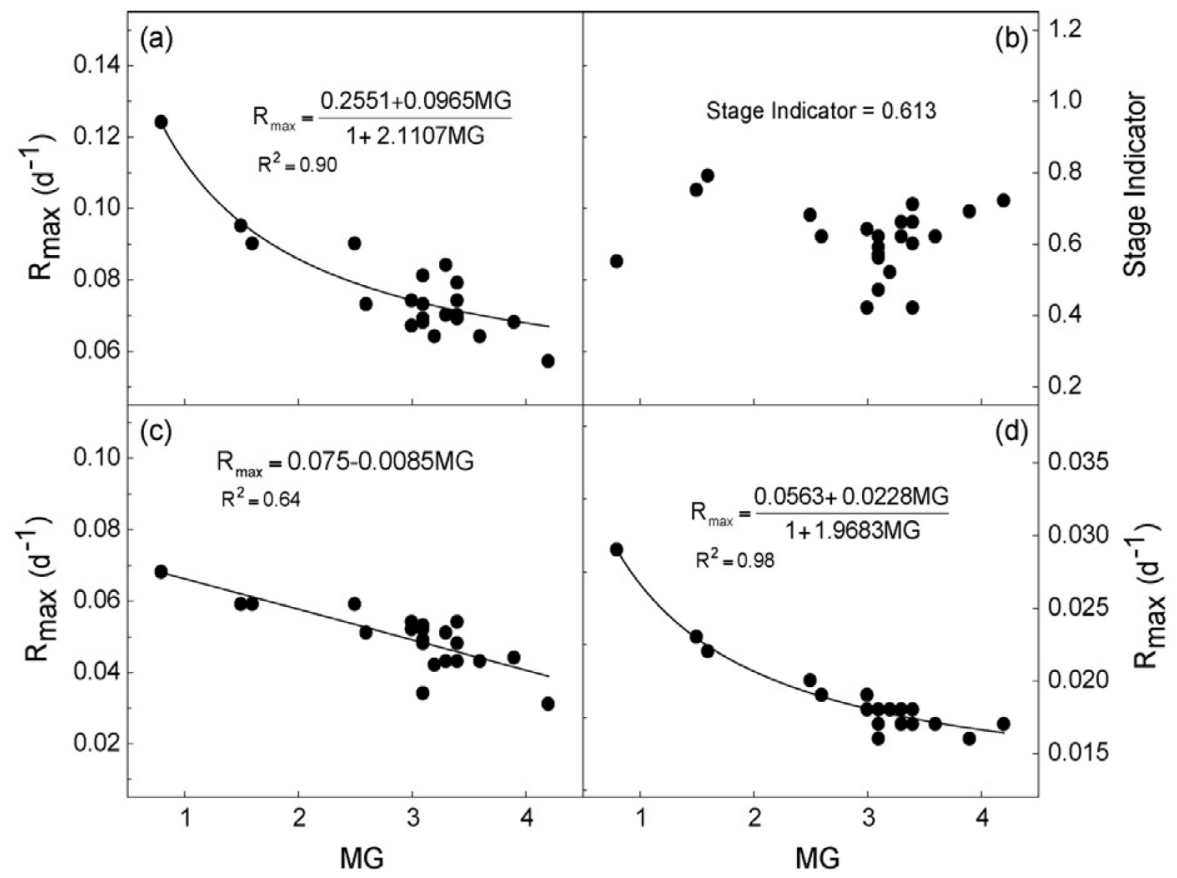

Figure 11. SOYDEV parameter generalization for $\mathrm{R}_{0}-\mathrm{R}_{1}(\mathrm{a}), \mathrm{R}_{1}-\mathrm{R}_{3.5}(\mathrm{~b}), \mathrm{R}_{1}-\mathrm{R}_{5}$ (c), and $\mathrm{R}_{1}-\mathrm{R}_{7}$ (d). $R_{\max }$ or mid-phase coefficients calibrated against observed phenology of soybeans planted on 5 May 2005 and 28 April 2004 were plotted against maturity group rating (MG) while photoperiod response parameters, $P_{\text {crt }}$ and $P_{\text {opt }}$, were held constant. 


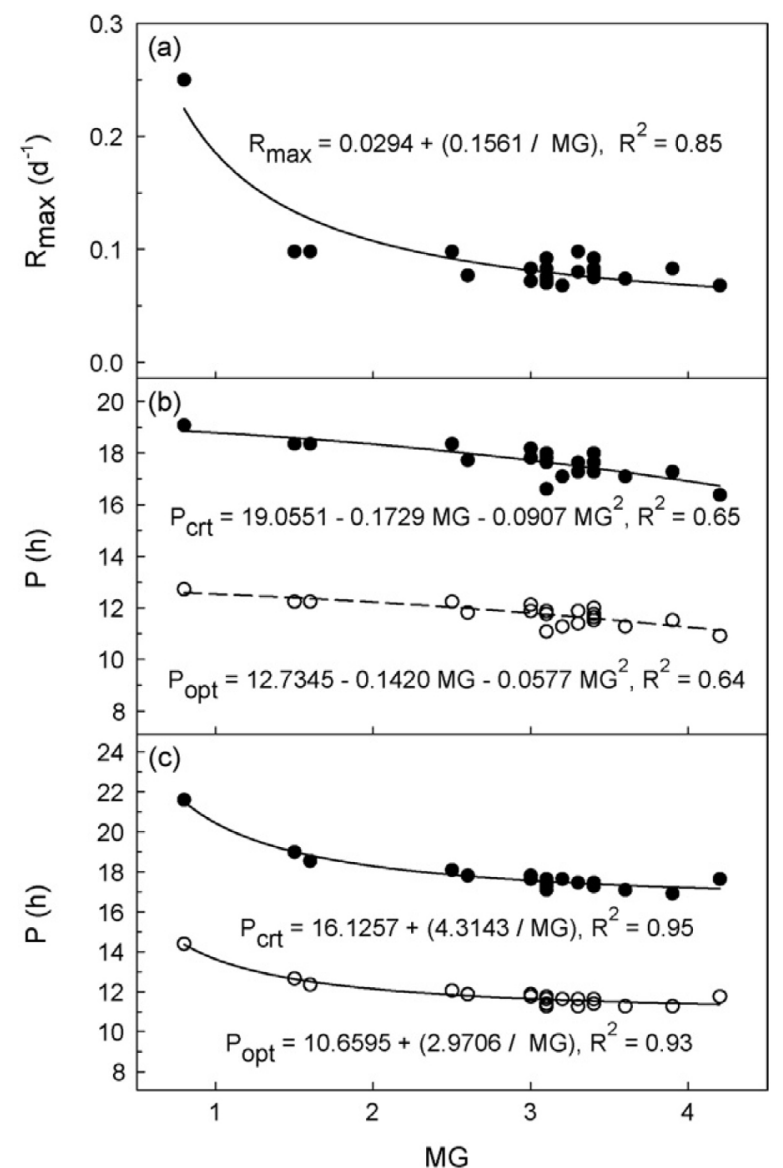

Figure 12. SOYDEV parameter generalization for $\mathrm{V}_{0}-\mathrm{R}_{0}(\mathrm{a}), \mathrm{R}_{1}-\mathrm{R}_{5}$ (b), and $\mathrm{R}_{1}-\mathrm{R}_{7}$ (c). $R_{\max }$ for $\mathrm{V}_{0}-\mathrm{R}_{0}, P_{\text {opt }}$, and $P_{\text {crt }}$ calibrated against observed phenology of soybeans planted on 5 May 2005 and 28 April 2004 were plotted against maturity group rating (MG) while $R_{\max }$ for $\mathrm{R}_{0}-\mathrm{R}_{1}, \mathrm{R}_{1}-\mathrm{R}_{5}$, and $\mathrm{R}_{1}-\mathrm{R}_{7}$ phases were held constant.

(Figure 10). Compared to the fully calibrated option, RMSE across stages and years increased by only 0.3 day in the $R_{\max }{ }^{-}$ based (Figure 10c) or 0.5 day in the photoperiod-based generalized modes (Figure 10d).

\section{Discussion}

Floral induction $\left(\mathrm{V}_{0}-\mathrm{R}_{0}\right)$ and post-induction $\left(\mathrm{R}_{0}-\mathrm{R}_{1}\right)$ are crucial determinants of flowering time in soybean and other photoperiod-inducible plants. While floral induction is affected by daylength (Garner and Allard, 1920), post-induction appears to be solely dependent on temperature in a sequential manner (Heatherly and Elmore, 2004). Three phases describing flowering progress were used in SOYDEV: (1) pre-induction (emergence to $\mathrm{V}_{0}$ ), (2) induction $\left(\mathrm{V}_{0}-\mathrm{R}_{0}\right)$, and (3) post-induction $\left(\mathrm{R}_{0}-\mathrm{R}_{1}\right)$. This three phases concept of progress toward flowering was suggested by Shanmugasundaram and Tsou (1978), Ellis et al. (1992), Collinson et al. (1993), and Upadhyay et al. (1994), and is also used in another soybean phenology model (Hodges and French, 1985). Further studies across a wider range of conditions are needed to confirm the post-induction insensitive to photoperiod and to identify the appropriate phases of floral induction. The assumption of $\mathrm{V}_{0}$ as the beginning of floral induction phase was based on the hypothe- sis that at the cotyledon stage, unifoliate leaves are starting to unroll and they can serve as the initial receptors for photoperiod induction (Bastidas, 2005). As for the optimal duration, it was assumed that four short-day cycles are required to complete floral induction (Blaney and Hamner, 1957).

Empirical evidence supporting that the hypothesis that photoperiod may control any or all stages of reproductive development was established as early as 1960 (Johnson et al., 1960). Shibles (1978) hypothesized that the photoperiod responsiveness at the late stages of reproductive growth allows some degree of seasonal adaptation independent of time of flowering that can be useful in fine-tuning vegetative growth, even when early flowering is promoted by late sowing. Results from this study confirm the need for including photoperiod response in modeling post-flowering stages $\left(\mathrm{R}_{5}\right.$ and $\left.\mathrm{R}_{7}\right)$. Photoperiod response was also accounted for in simulation of post-flowering stages in CROPGRO. The ability of SOYDEV to simulate previously documented effects of sowing date on the number of main stem nodes in soybean (Bastidas, 2005) relies on the interaction between vegetative and reproductive development and the effect of sowing dates on V-stage parameters, namely the $V_{\Delta}$ and the maximum node appearance rate. Shorter $R_{1}-R_{5}$ duration, lower maximum node appearance rate, and shorter $\mathrm{R}_{1}-\mathrm{V}_{\Delta}$ duration cause late planted soybeans to have fewer final main stem nodes than earlier planted ones. The relationship between $R_{5}$ and the cessation of leaf emergence was suggested by Sinclair (1984). The effect of sowing date on V-stage parameters may be linked to the interaction between phenology and growth and is of interest for future investigation.

An interesting observation from this study was the different nature of soybean node appearance and flowering in response to temperature and daylength. The delay in floral induction at later sowing dates, due to longer daylength, was not discernable in terms of duration from emergence to $\mathrm{R}_{1}$ phase (Figure 7) because higher temperatures later in the growing season apparently shorten the duration of the post-induction phase. Both flowering (post-induction) and node appearance respond to temperature, but only flowering (induction) responds to daylength. Therefore, comparing $\mathrm{R}_{1}$ occurrence with respect to the V-stage allows the daylength effect on flowering (induction) to be compared between the different sowing dates without the confounding effect of temperature. The effect of daylength on floral induction was evident when $\mathrm{R}_{1}$ occurrences on different sowing dates were compared with respect to the V-stage. Plants that were sown on 15 April, 4 May, and 17 June (15.3, 15.7, and $16.2 \mathrm{~h}$ of daylength at $\mathrm{V}_{0}$ ) reached $\mathrm{R}_{1}$ at $\mathrm{V}_{5.7}, \mathrm{~V}_{7.5}$ and $\mathrm{V}_{8.4}$, respectively.

In evaluating the performance of any soybean phenology model, it is necessary to consider the level of accuracy of the observed data. Uncertainties associated with observed data include the nature of the staging system and plant-to-plant variability. While spatial error is introduced by field variability, temporal error exists because the staging system used here (Fehr and Caviness, 1977) is not measurably continuous. In other words, the visually observable phenological stage assigned in the field may suggest no change from 1 day to the next although the plant continues its phenological develop- 


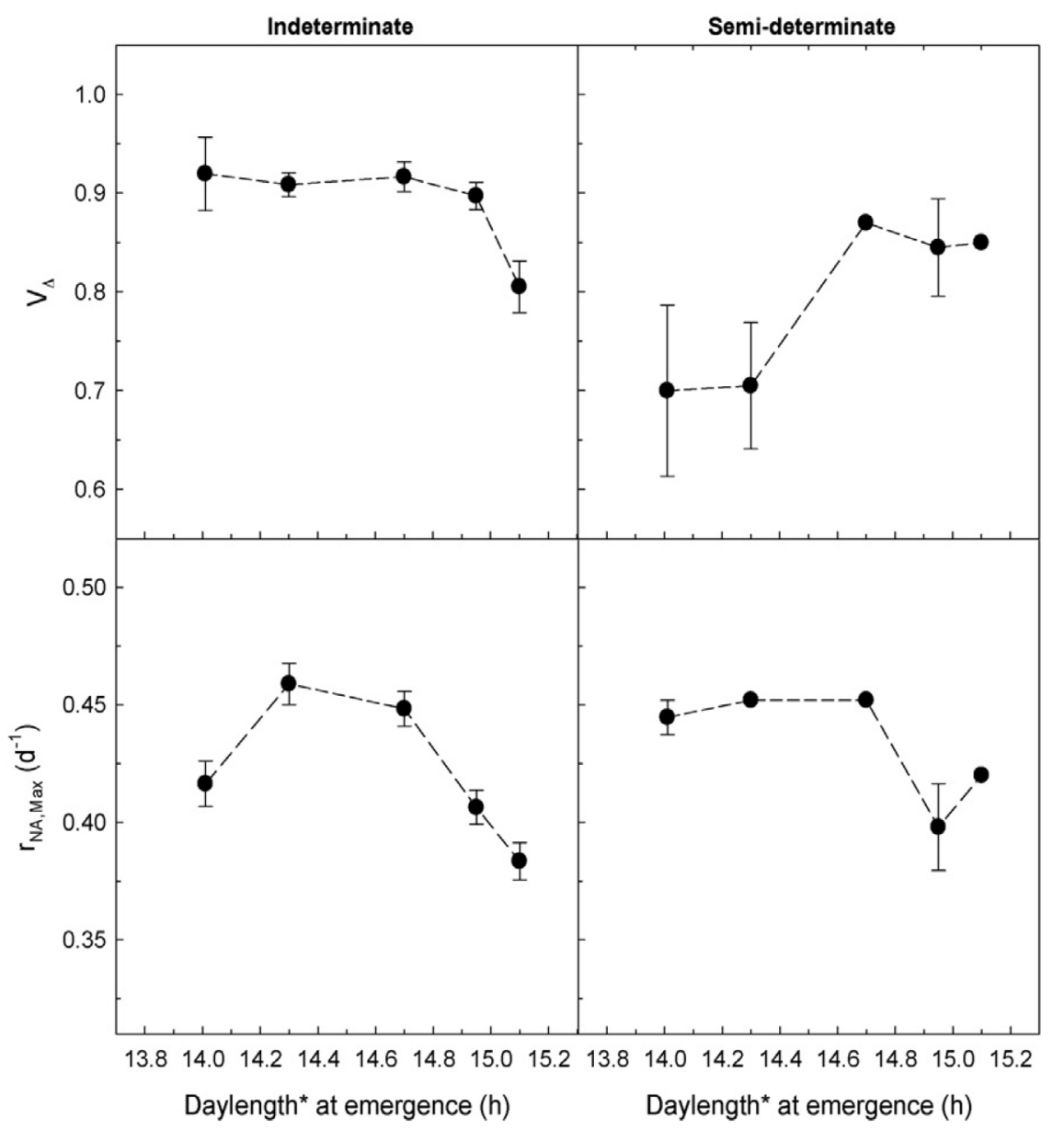

Figure 13. V-stage parameters, $\mathrm{V}_{\Delta}$ and maximum main stem node appearance rate, $r_{\mathrm{LA} \text {,max }}$ for the indeterminate (left) and semi-determinate (right) as affected by daylength at emergence. Symbols and bars indicate mean and standard errors of the parameters obtained from calibration using data from all cultivars of the same stem termination type in the cultivar $\times$ sowing date experiment in 2004 and 2005. Daylength was defined as daylight duration when solar elevation was above $-0.83^{\circ}$.

ment. Considering the uncertainties in observed data, both SOYDEV and CROPGRO provided acceptable simulation of soybean phenology in the long-term high-yield study (Figure 9), with a small, but consistently superior performance of SOYDEV. Both models attempt to mechanistically describe soybean development, but in different ways and with different empirical parameters. SOYDEV simulates floral induction and post-induction and uses non-linear temperature and photoperiod functions. In contrast, CROPGRO calculates the rate of development in an hourly time step using generated hourly temperature (from daily maximum and minimum temperatures) (Parton and Logan, 1981) and a linear spline function (Jones et al., 2000).

Methods for defining and calculating daylength differ between SOYDEV and CROPGRO. In CROPGRO, daylength was calculated with the Spitters et al. (1986) method in which daylength is defined as the daylight duration when solar elevation $\geq 0^{\circ}$. In SOYDEV daylength was calculated using the algorithm described in Keisling (1982) which allows a more flexible definition of daylength depending on solar elevation. Daylength influencing floral induction in SOYDEV was daylight duration when solar elevation $\geq-6.00^{\circ}$, while daylength influencing post-flowering development was based on solar elevation $\geq-0.83^{\circ}$. Solar elevation of $-6.00^{\circ}$ is known as civil twilight while solar elevation of $-0.83^{\circ}$ is when the upper edge of the disk of the sun is on the horizon (Seidelmann, 1992). The different daylength definition used in SOYDEV for postflowering versus floral induction phases suggests that the presumed post-flowering developmental response to daylength may involve a distinct underlying mechanism other than that of floral induction. The use of civil twilight to describe the effect of daylength on floral induction was suggested by Downs and Thomas (1990) and was used in an experiment investigating photoperiod sensitivity in soybean (Ellis et al., 1992). Daylength based on solar elevation of $-0.83^{\circ}$ was used for the post- $\mathrm{R}_{1}$ phase as results from this series of experiments indicated a more accurate phenology simulation was achieved using this daylength definition (data not shown). We speculate that post- $\mathrm{R}_{1}$ phenology was associated with the daily photosynthetic duration, which most likely does not respond to civil twilight illumination levels.

Further research is needed to evaluate cardinal daylengths $\left(P_{\text {opt }}\right.$ and $\left.P_{\text {crt }}\right)$ describing the effect of daylength on post-flowering development $\left(\mathrm{R}_{1}-\mathrm{R}_{5}\right.$ and $\left.\mathrm{R}_{1}-\mathrm{R}_{7}\right)$. A clear understanding of the molecular mechanism of the presumed development response to daylength in late reproductive stages and its incor- 
poration into mathematical models remain critical toward a more mechanistic option in simulating soybean phenology.

Our results provide first indications that key model parameters needed to simulate soybean phenology on a cultivarspecific basic can be estimated from readily available cultivar information such as stem termination type and maturity group rating. This is a potential advantage of the new SOYDEV model, particularly with regard to practical applications in which it is not possible to conduct extensive cultivar-specific model calibrations, which are required for utilizing models such as CROPGRO.

In this study, only two types of stem termination were considered (indeterminate and semi-determinate). Stem termination types in soybean germplasm collections, however range qualitatively from very determinate to very indeterminate (Bernard et al., 1998). Quantification of the effect of genes such as $\mathrm{Dt}_{1} / \mathrm{dt}_{1}$ and $\mathrm{Dt}_{2} / \mathrm{dt}_{2}$ (Bernard, 1972) and $\mathrm{dt}_{1}$-t (Thompson et al., 1997) on the stem termination habit in soybean will be of future interest as it may lead to a more detailed parameterization of node appearance simulation in order to extend application of SOYDEV to a wider selection of stem termination types.

Maturity group ratings are by themselves of a more qualitative nature and they may vary depending on the experimental procedures used to assign a MG to a commercially available soybean variety. It remains to be seen whether the empirical relationships established for estimating $R_{\max }, P_{\mathrm{crt}}$ and $P_{\mathrm{opt}}$ (Figure 11 and Figure 12) hold for an even wider range of maturity group ratings grown under widely differing conditions and whether the relationships can be linked to the genes controlling flowering and maturity in soybean such as $\mathrm{E}_{1} / \mathrm{e}_{1}$ and $\mathrm{E}_{2} / \mathrm{e}_{2}$ (Bernard, 1971 and McBlain et al., 1987), $\mathrm{E}_{3} / \mathrm{e}_{3}$ (Buzell, 1971 and McBlain et al., 1987), $\mathrm{E}_{4} / \mathrm{e}_{4}$ (Buzell and Voldeng, 1980), $\mathrm{E}_{5} / \mathrm{e}_{5}$ (McBlain and Bernard, 1987), $\mathrm{E}_{6} / \mathrm{e}_{6}$ (Bonato and Vello, 1999), and $\mathrm{E}_{7} / \mathrm{e}_{7}$ (Cober et al., 2001). Likewise, the proposed SOYDEV model has only been tested under near-optimal conditions. Its performance needs to be further evaluated under abiotic stress, such as water and nutrient stresses.

\section{Conclusions}

Soybean phenology can be successfully simulated across a range of cultivars and sowing dates by the use of: (1) appropriate flowering phases based on an understanding of soybean flowering physiology, and (2) biologically reasonable, non-linear temperature and photoperiod response functions. This study also highlighted the interaction between vegetative and reproductive developments with respect to temperature and daylength in that: (1) longer daylength during the floral inductive phase at later planting dates caused $\mathrm{R}_{1}$ to occur at later V-stage, and (2) the earlier occurrence of $R_{5}$ limited the total number of nodes at later planting dates due to the earlier cessation of node appearance. SOYDEV holds promise for practical model applications because data input requirements can be kept to a minimum (sowing date, sowing depth, daily temperature, cultivar stem termination type, and cultivar maturity group rating) and key cultivar-specific parameters can be estimated from the published maturity group rating with little loss of prediction accuracy.

\section{Acknowledgements}

We thank the Nebraska Soybean Board, the Fluid Fertilizer Foundation (FFF), and the Foundation for Agronomic Research (FAR) for providing the funding for this research. We also thank Joe Mitchell, Travis Wegner, Darren Binder, and student workers for their help with field operations, phenology staging, sampling, and sample processing. Contribution of the University of Nebraska Agric. Res. Div., Lincoln, NE. Journal Ser. no. 15205.

\section{References}

Bastidas, 2005: A. M. Bastidas, 2005. Soybean growth, development, and yield. The effect of planting date. M. S. Thesis. Univ. of Nebraska-Lincoln, Lincoln, NE.

Bernard, 1971: R. L. Bernard, Two major genes for time of flowering and maturity in soybeans, Crop Sci. 11 (1971), pp. 242-244.

Bernard, 1972: R. L. Bernard, Two genes affecting stem termination in soybeans, Crop Sci. 12 (1972), pp. 235-239.

Bernard et al., 1998: R. L. Bernard, C. R. Cremeens, R. L. Cooper, F. I. Collins, K. L. Krober, K. L. Athow, F. A. Laviolette, C. J. Coble, and R. L. Nelson, 1998. Evaluation of the USDA soybean germplasm collection: maturity group 000-IV (FC 01. 547-PI 266. 807). USDA-ARS Technical Bulletin 1844. Washington, DC, U. S. Government Printing Office.

Blaney and Hamner, 1957: L. T. Blaney and K. C. Hamner, Interrelations among effects of temperature, photoperiod, and dark period on floral initiation of Biloxi soybean, Bot. Gaz. 119 (1957), pp. 10-24.

Bonato and Vello, 1999: E. R. Bonato and N. A. Vello, E6, a dominant gene conditioning early flowering and maturity in soybeans, Genet. Mol. Biol. 22 (1999), pp. 229-232.

Boogard et al., 1998: H. L. Boogard, C. A. van Diepen, R. P. Rötter, J. M. C. A. Cabrera, and H. H. van Laar, 1998. User's guide for the WOFOST 7. 1 crop growth simulation model and WOFOST Control Center 1. 5 . Technical Document 52. DLO Winand Staring Centre, Wageningen, The Netherlands.

Brevedan and Egli, 2003: R. E. Brevedan and D. B. Egli, Short periods of water stress during seed filling, leaf senescence, and yield of soybean, Crop Sci. 43 (2003), pp. 2083-2088.

Brisson et al., 1998: N. Brisson, B. Mary, D. Ripoche, M. H. Jeuffroy, F. Ruget, B. Nicoullaud, P. Gate, F. Devienne-Barret, R. Antonioletti, C. Durr, G. Richard, N. Beaudoin, S. Recous, X. Tayot, D. Plenet, P. Cellier, J. M. Machet, J. M. Meynard and R. Delécolle, STICS: a generic model for the simulation of crops and their water and nitrogen balances. I. Theory and parameterization applied to wheat and corn, Agronomie 18 (1998), pp. 311-346.

Brisson et al., 2003: N. Brisson, C. Gary, E. Justes, R. Roche, B. Mary, D. Ripoche, D. Zimmer, J. Sierra, P. Bertuzzi, P. Burger, F. Bussière, Y. M. Cabidoche, P. Cellier, P. Debaeke, J. P. Gaudillère, C. Hénault, F. Maraux, B. Seguin and H. Sinoquet, An overview of the crop model STICS, Eur. J. Agron. 18 (2003), pp. 309-332.

Brown and Chapman, 1960: D. M. Brown and L. J. Chapman, Soybean ecology. II. Development-temperature-moisture relationship from field studies, Agron. J. 52 (1960), pp. 496-499.

Buzell, 1971: R. I. Buzell, Inheritance of a soybean flowering response to fluorescent-daylength conditions, Can. J. Genet. Cytol. 13 (1971), pp. 703-707.

Buzell and Voldeng, 1980: R. I. Buzell and H. D. Voldeng, Inheritance of sensitivity to long daylength, Soybean Genet. Newsl. 7 (1980), pp. 26-29.

Cober et al., 2001: E. R. Cober, D. W. Steward, and H. D. Voldeng, Photoperiod and temperature response in early-maturing, near isogenic soybean lines, Crop Sci. 41 (2001), pp. 721-727.

Collinson et al., 1993: S. T. Collinson, R. J. Summerfield, R. H. Ellis and E. H. Roberts, Durations of the photoperiod-sensitive and photoperiod-insensitive phases of development to flowering in four cultivars of soybean [Glycine max (L) Merrill], Ann. Bot. 71 (1993), pp. 389-394.

Cregan and Hartwig, 1984: P. B. Cregan and E. E. Hartwig, Characterization of flowering response to photoperiod in diverse soybean genotypes, Crop Sci. 24 (1984), pp. 659-662.

Downs and Thomas, 1990: J. R. Downs and J. F. Thomas, Morphology and reproductive development of soybean under artificial conditions, Biotronics 19 (1990), pp. 19-32.

Ellis et al., 1992: R. H. Ellis, S. T. Collinson, D. Hudson and W. M. Patefield, The analysis of reciprocal transfer experiments to estimate the durations 
of the photoperiod-sensitive and photoperiod-insensitive phases of plant development: an example in soya bean, Ann. Bot. 70 (1992), pp. 87-92.

Fehr and Caviness, 1977: W. R. Fehr and C. E. Caviness, Stages of Soybean Development, Cooperative Extension Service, Agriculture and Home Economics Experiment Station Iowa State University, Ames, Iowa (1977).

Ferguson et al., 2003: R. B. Ferguson, C. A. Shapiro, A. Dobermann and C. S. Wortmann, Fertilizer Recommendations for Soybean. NebGuide G87859-A, Cooperate Extension, Institute of Agriculture and Natural Resources, University of Nebraska-Lincoln, Lincoln, NE (2003).

Garner and Allard, 1920: W. W. Garner and H. A. Allard, Effect of the relative length of the day and night and other factors of the environment on growth and reproduction in plants, J. Agric. Res. 18 (1920), pp. 553-605.

Grimm et al., 1993: S. S. Grimm, J. W. Jones, K. J. Boote and J. D. Hesketh, Parameter estimation for predicting flowering date of soybean cultivars, Crop Sci. 33 (1993), pp. 137-144.

Grimm et al., 1994: S. S. Grimm, J. W. Jones, K. J. Boote and D. C. Herzog, Modeling the occurrence of reproductive stages after flowering for four soybean cultivars, Agron. J. 86 (1994), pp. 31-38.

Han et al., 2006: T. Han, C. Wu, Z. Tong, R. S. Mentreddy, K. Tan and J. Gai, Postflowering photoperiod regulates vegetative growth and reproductive development of soybean, Environ. Exp. Bot. 55 (2006), pp. 120-129.

Heatherly and Elmore, 2004: L. G. Heatherly and R. W. Elmore, Managing inputs for peak production. In: H. R. Boerma and J. E. Specht, Editors, Soybean: Improvement, Production, and Uses, ASA-CSSA-SSSA, Madison, WI (2004), pp. 451-536.

Hesketh et al., 1973: J. D. Hesketh, D. L. Myhre and C. R. Willey, Temperature control of time intervals between vegetative and reproductive events in soybeans, Crop Sci. 13 (1973), pp. 250-254.

Hodges and French, 1985: T. Hodges and V. French, Soyphen: soybean growth stages modeled from temperature, daylength, and water availability, Agron. J. 77 (1985), pp. 500-505.

Janssen and Heuberger, 1995: P. H. M. Janssen and P. S. C. Heuberger, Calibration of process-oriented models, Ecol. Model. 83 (1995), pp. 55-66.

Johnson et al., 1960: H. W. Johnson, H. A. Borthwick and R. C. Leffel, Effects of photoperiod and time of planting on rates of development of the soybean in various stages of the life cycle, Bot. Gaz. 122 (1960), pp. $77-95$.

Jones et al., 2000: J. W. Jones, J. White, K. Boote, G. Hoogenboom and C. H. Porter, Phenology Module in DSSAT v 4. 0. Documentation and Source Code Listing, Agricultural and Biological Engineering Department, University of Florida, Gainesville, FL (2000).

Kadhem et al., 1985a: F. A. Kadhem, J. E. Specht and J. H. Williams, Soybean irrigation serially timed during stages $\mathrm{R}_{1}$ to $\mathrm{R}_{6}$. II. Yield component responses, Agron. J. 77 (1985), pp. 299-304.

Kadhem et al., 1985b: F. A. Kadhem, J. E. Specht and J. H. Williams, Soybean irrigation serially timed during stages $R_{1}$ to $R_{6}$. I. Agronomic responses, Agron. J. 77 (1985), pp. 291-298.

Keisling, 1982: T. C. Keisling, Calculation of the length of day, Agron. J. 74 (1982), pp. 758-759.

Korte et al., 1983a: L. L. Korte, J. E. Specht, J. H. Williams and R. C. Sorensen, Irrigation of soybean genotypes during reproductive ontogeny. II. Yield component responses, Crop Sci. 23 (1983), pp. 528-533.

Korte et al., 1983b: L. L. Korte, J. E. Specht, J. H. Williams and R. C. Sorensen, Irrigation of soybean genotypes during reproductive ontogeny. I. Agronomic responses, Crop Sci. 23 (1983), pp. 521-527.

Leopold and Kriedemann, 1975: A. C. Leopold and P. E. Kriedemann, Plant growth and Development, McGraw-Hill Book Company, New York (1975).

Major et al., 1975: D. J. Major, D. R. Johnson, J. W. Tanner and I. C. Anderson, Effects of daylength and temperature on soybean development, Crop Sci. 15 (1975), pp. 174-179.

McBlain and Bernard, 1987: B. A. McBlain and R. L. Bernard, A new gene affecting the time of flowering and maturity in soybeans, J. Hered. 78 (1987), pp. 160-162.

McBlain et al., 1987: B. A. McBlain, J. D. Hesketh and R. L. Bernard, Genetic effects on reproductive phenology in soybean isolines differing in maturity genes, Can. J. Plant Sci. 67 (1987), pp. 105-116.

Naylor, 1953: A. W. Naylor, Reactions of plants to photoperiod. In: W. E Loomis, Editor, Growth and Differentiation in Plants. A Monograph of the American Society of Plant Physiologist, The Iowa State College Press, Ames, IA (1953), pp. 149-178.

Parton and Logan, 1981: W. J. Parton and J. A. Logan, A model for diurnal variation in soil and air temperature, Agric. Meteorol. 23 (1981), pp. 205-216.

Robins and Domingo, 1956: J. S. Robins and C. E. Domingo, Moisture deficit in relation to growth and development of dry beans, Agron. J. 48 (1956), pp. 67-70.
SAS Institute, 1999: SAS Institute, The SAS System for Windows. Release 8. 02, SAS Institute, Cary, NC (1999).

Seidelmann, 1992: P. K. Seidelmann, Explanatory Supplement to the Astronomical Almanac, University Science Books, Herndon, VA (1992).

Shanmugasundaram and Tsou, 1978: S. Shanmugasundaram and S. C. S. Tsou, Photoperiod and critical duration for flower induction in soybean, Crop Sci. 18 (1978), pp. 598-601.

Shibles, 1978: R. Shibles, Adaptation of soyabeans to different seasonal durations. In: R. J. Summerfield and A. H. Bunting, Editors, Advances in Legume Sciences, Royal Botanic Gardens, Kew, England (1978), pp. 279-285.

Sinclair, 1984: T. R. Sinclair, Cessation of leaf emergence in indeterminate soybeans, Crop Sci. 24 (1984), pp. 483-486.

Sinclair and deWit, 1975: T. R. Sinclair and C. T. deWit, Comparative analysis of photosynthate and nitrogen requirement in the production of seed by various crops, Science 189 (1975), pp. 565-567.

Sinclair and deWit, 1976: T. R. Sinclair and C. T. deWit, Analysis of the carbon and nitrogen limitation to soybean yield, Agron. J. 68 (1976), pp. 319-324.

Sinclair et al., 1991: T. R. Sinclair, S. Kitani, K. Hinson, J. Bruniard and T. Horie, Soybean flowering date: linear and logistic models based on temperature and photoperiod, Crop Sci. 31 (1991), pp. 786-790.

Specht et al., 1989: J. E. Specht, R. W. Elmore, D. E. Eisenhauer and N. W. Klocke, Growth stage scheduling criteria for soybeans, Irrigation Sci. 10 (1989), pp. 99-111.

Spitters et al., 1986: C. J. T. Spitters, H. A. J. M. Toussaint and J. Goudriaan, Separating the diffuse and direct component of global radiation and its implications for modeling canopy photosynthesis. Part 1. Components of incoming radiation, Agric. For. Meteorol. 38 (1986), pp. 217-229.

Steward et al., 2003: D. W. Steward, E. R. Cober and R. L. Bernard, Modeling genetic effects on the photothermal response of soybean phenological development, Agron. J. 95 (2003), pp. 65-70.

Streck et al., 2003: N. A. Streck, A. Weiss, Q. Xue and P. S. Baenziger, Improving predictions of developmental stages in winter wheat, Agric. For Meteorol. 115 (2003), pp. 139-150.

Summerfield and Wilcox, 1978: R. J. Summerfield and J. R. Wilcox, Effects of photoperiod and air temperature on growth and yield of economic legumes. In: R. J. Summerfield and A. H. Bunting, Editors, Advances in Legume Sciences, Royal Botanic Gardens, Kew, England (1978), pp. $17-36$.

Summerfield et al., 1991: R. J. Summerfield, E. H. Roberts, R. H. Ellis and R. J. Lawn, Towards the reliable prediction of time to flowering in seven annual crops. I. The development of simple models for fluctuating field environments, Exp. Agric. 27 (1991), pp. 11-31.

Summerfield et al., 1998: R. J. Summerfield, H. Asumadu, R. H. Ellis and A. Qi, Characterization of the photoperiodic response of post-flowering development in maturity isolines of soyabean [Glycine max (L) Merrill] 'Clark', Ann. Bot. 82 (1998), pp. 765-771.

Taiz and Zeiger, 1991: L. Taiz and E. Zeiger, Plant Physiology, The Benjamin/Cummings Publishing Company Inc., Redwood City, CA (1991).

Thomas and Vince-Prue, 1997: B. Thomas and D. Vince-Prue, Photoperiodism in Plants, Academic Press, San Diego, CA, USA (1997) pp. 63-84.

Thompson et al., 1997: J. A. Thompson, R. L. Bernard and R. L. Nelson, A third allele at the soybean dt ${ }_{1}$ locus, Crop Sci. 37 (1997), pp. 757-762.

Trewavas, 1986: A. Trewavas, Understanding the control of plant development and the role of growth substances, Aust. J. Plant. Physiol. 13 (1986), pp. 447-457.

Upadhyay et al., 1994: A. P. Upadhyay, R. J. Summerfield, R. H. Ellis, E. H. Roberts and A. Qi, Variation in the duration of the photoperiod-sensitive and photoperiod-insensitive phase of development to flowering among eight maturity isolines of soyabean [Glycine max (L) Merrill], Ann. Bot. 74 (1994), pp. 87-96.

Wallace et al., 1993: D. H. Wallace, R. W. Zobel and K. S. Yourstone, A whole-system reconsideration of paradigms about photoperiod and temperature control of crop yield, Theor. Appl. Genet. 86 (1993), pp. 17-26.

Wang and Engel, 1998: E. Wang and T. Engel, Simulation of phenological development of wheat crops, Agric. Syst. 58 (1998), pp. 1-24.

Wilhelm and McMaster, 1995: W. W. Wilhelm and G. S. McMaster, The importance of the phyllochron in studying development and growth of grasses, Crop Sci. 35 (1995), pp. 1-3.

Yin et al., 1995: X. Yin, M. J. Kropff, G. McLaren and R. M. Visperas, A nonlinear model for crop development as a function of temperature, $\mathrm{Ag}$ ric. For. Meteorol. 77 (1995), pp. 1-16.

Zobel, 1992: R. W. Zobel, Soil environment constraints to root growth, Adv. Soil Sci. 19 (1992), pp. 27-51. 